University of Nebraska - Lincoln

DigitalCommons@University of Nebraska - Lincoln

1996

\title{
AN ECOLOGICAL RISK ASSESSMENT OF LEAD SHOT EXPOSURE IN NON-WATERFOWL AVIAN SPECIES: UPLAND GAME BIRDS AND RAPTORS
}

\author{
Ronald J. Kendall \\ Clemson University \\ Thomas E. Lacher Jr. \\ Clemson University \\ Christine Bunck \\ National Biological Service \\ Bernard Daniel \\ U.S. Environmental Protection Agency \\ Crystal Driver \\ Battelle Pacific Northwest Laboratories \\ See next page for additional authors
}

Follow this and additional works at: https://digitalcommons.unl.edu/usepapapers

Kendall, Ronald J.; Lacher, Thomas E. Jr.; Bunck, Christine; Daniel, Bernard; Driver, Crystal; Grue, Christian E.; Leighton, Frederick; Stansley, William; Watanabe, Philip G.; and Whitworth, Molly, "AN ECOLOGICAL RISK ASSESSMENT OF LEAD SHOT EXPOSURE IN NON-WATERFOWL AVIAN SPECIES: UPLAND GAME BIRDS AND RAPTORS" (1996). U.S. Environmental Protection Agency Papers. 135.

https://digitalcommons.unl.edu/usepapapers/135

This Article is brought to you for free and open access by the U.S. Environmental Protection Agency at DigitalCommons@University of Nebraska - Lincoln. It has been accepted for inclusion in U.S. Environmental Protection Agency Papers by an authorized administrator of DigitalCommons@University of Nebraska - Lincoln. 


\section{Authors}

Ronald J. Kendall, Thomas E. Lacher Jr., Christine Bunck, Bernard Daniel, Crystal Driver, Christian E. Grue, Frederick Leighton, William Stansley, Philip G. Watanabe, and Molly Whitworth 


\title{
AN ECOLOGICAL RISK ASSESSMENT OF LEAD SHOT EXPOSURE IN NON-WATERFOWL AVIAN SPECIES: UPLAND GAME BIRDS AND RAPTORS
}

\author{
Ronald J. Kendall, $* \dagger$ Thomas E. Lacher, JR. $\ddagger$ Christine Bunck, $§$ Bernard Daniel, $\|$ \\ Crystal Driver,\# Christian E. Grue, I Frederick Leighton,** William Stansley, $\dagger \dagger$ \\ Philip G. WATANABE $\ddagger \ddagger$ and Molly WhitworTh $\S$ \\ $\dagger$ The Institute of Wildlife and Environmental Toxicology (TIWET), P.O. Box 709, One TIWET Drive, \\ Clemson University, Pendleton, South Carolina 29670 USA \\ $\$$ Archbold Tropical Research Center, Clemson University, Clemson, South Carolina 29634-1019 USA \\ $\S$ Biomonitoring of Environmental Status and Trends Program, \\ National Biological Service, 1849 C Street, N.W., Washington, DC 20240 USA \\ Ecological Monitoring Research Division, \\ U.S. Environmental Protection Agency, Cincinnati, Ohio 45268 USA \\ \#Battelle Pacific Northwest Laboratories, Environmental Sciences (MS K4-12), Box 999, \\ Richland, Washington 99352 USA \\ IINational Biological Service, Washington Cooperative Fish \& Wildlife Research Unit, School of Fisheries, \\ University of Washington, Seattle, Washington 98107 USA \\ **Canadian Cooperative Wildlife Health Center, \\ Western College of Veterinary Medicine, \\ University of Saskatchewan, 52 Campus Drive, Saskatoon, SK S7N 5B4, Canada \\ $\dagger+$ New Jersey Division of Fish, Game, and Wildlife, Office of Fish and Wildlife Health and Forensics, \\ P.O. Box 394, Lebanon, New Jersey 08833 \\ \$The Dow Chemical Company, Health and Environmental Sciences, 1803 Building, Midland, Michigan 48674 USA \\ $\S \S U . S$. Environmental Protection Agency, Room 415, West Tower, \\ 401 M Street, S.W., Washington, DC 20460 USA
}

(Received 22 February 1995; Accepted 19 May 1995)

\begin{abstract}
There is increasing concern that birds in terrestrial ecosystems may be exposed to spent lead shot. Evidence exists that upland birds, particularly mourning doves (Zenaida macroura), ingest spent lead shot and that raptors ingest lead shot by consuming wounded game. Mortality, neurological dysfunction, immune suppression, and reproductive impairment are documented effects of exposure to lead in birds. An ecological risk assessment on the impact of lead shot exposure in upland birds was conducted and is presented in the context of the new United States Environmental Protection Agency's Ecological Risk Assessment Paradigm. A considerable amount of spent lead shot is released into the environment each year from shooting and hunting. Doves collected from fields that are cultivated to attract mourning doves for hunting activities show evidence of ingestion of spent lead shot. Because lead can cause both acute and chronic toxicity if ingested by birds, and because there is evidence of widespread deposition of lead shot in terrestrial ecosystems, concern for impacts on upland game birds and raptors seems warranted. Although this ecological risk assessment does not clearly define a significant risk of lead shot exposure to upland game birds, this issue merits continued scrutiny to protect our upland game bird and raptor resources.
\end{abstract}

Keywords-Environmental risk assessment Lead shot Wildlife Non-waterfowl Shooting sports

\section{INTRODUCTION}

There is a growing concern about the exposure of non-waterfowl species to spent lead shot from hunting activities and shooting ranges. This concern is accentuated by recent regulations by the Environmental Protection Agency (EPA) on the use of lead sinkers for fishing. These regulations are being enacted because certain species of waterfowl are ingesting lead, resulting in mortality. Lead shot regulation for non-waterfowl bird species will likely become an issue in the near future. The workshop "Lead Shot Exposure in Non-waterfowl Species: An Ecological Risk Assessment" was commissioned to address this issue. The workshop was funded by the National Wildlife Federation (NWF), the EPA, and the National Shooting Sports

* To whom correspondence may be addressed.

TIWET Contribution 9501, Clemson University, Clemson, SC, and Technical Contribution 4081, South Carolina Agricultural Experiment Station.
Foundation (NSSF). The goal of the workshop was to develop an ecological risk assessment for the exposure of upland bird species to spent lead shot, in the format of the EPA's Risk Assessment Forum publication, A Framework for Ecological Risk Assessment [1] (Fig. 1).

The distribution of lead shot in the environment is continuing through hunting activities. In addition, potential exposure for non-waterfowl bird species is increasing on shooting preserves and through the expansion of target shooting activities. It appears that ingestion of spent lead shot is the most common means of exposure to lead in upland game birds, particularly mourning doves (Zenaida macroura). Raptors can be exposed by eating birds that have been embedded with lead shot. This ingestion of tissue-incorporated shot might also pose a significant risk.

Our charge was broad and required significant definition by our Risk Assessment Panel. The NWF requested information 


\section{Framework for Ecological Risk Assessment}

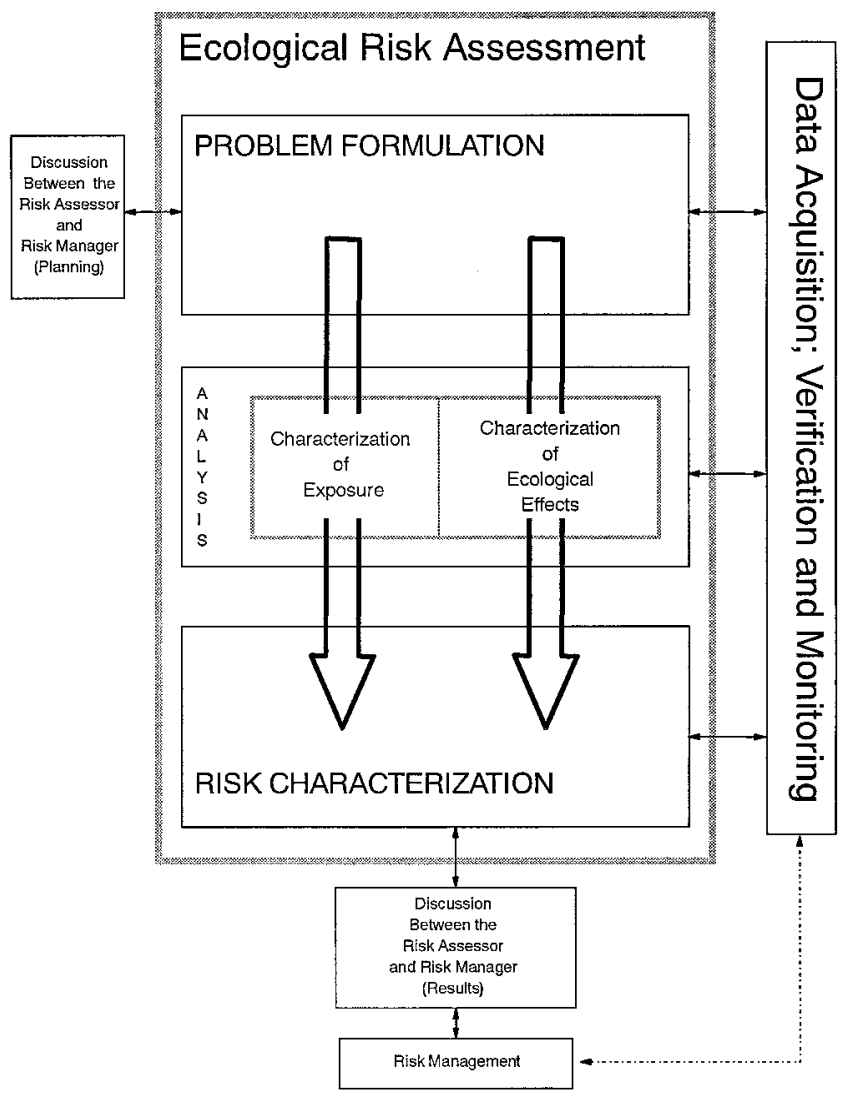

Fig. 1. United States Environmental Protection Agency's framework for ecological risk assessment.

on "how the release of shotgun pellets contributes to the total lead in the environment and what, if any, are the documented effects on wildlife health, particularly related to upland game birds and potentially other bird species" (W. Howard personal communication). The Risk Assessment Panel identified objectives for the project consistent with the wishes of the NWF in order to develop a conceptual model for lead shot exposures using the ecological risk assessment framework proposed by the EPA [1]. Examining scientific information in the context of an ecological risk assessment is a new and evolving process. The goal of our workshop was to define the status of knowledge on the ecological risk of lead shot released into the environment and thereby contribute to the development of the ecological risk assessment process. In addition, we assessed the potential risk to upland bird species that results from ingestion of spent lead shot. A careful review of available scientific data was used to evaluate the potential for exposure to lead shot and the likelihood that this exposure might produce adverse ecological effects. This paper will serve as an example demonstrating the utility of the ecological risk framework. This ecological risk assessment will be important in further developing and validating the process and in guiding future regulatory activities in procedures that make appropriate scientific decisions based on available data.

\section{PROBLEM FORMULATION}

Spent lead shot was identified as a major environmental concern in waterfowl health as a result of numerous studies that began in the early 1900s and intensified in the late 1950s. These studies identified the ingestion of spent lead shot as a major hazard to North American waterfowl [2-4]. For example, waterfowl surveys suggested that up to $7 \%$ of birds ingested at least one lead shot pellet annually and that approximately $2 \%$ succumbed to lead toxicosis [5]. In North America it was estimated that between 1.5 and 2.5 million waterfowl were lost annually to lead poisoning [5-7].

The principal cause of lead poisoning was the deposition of high densities of lead shot in sediments associated with hunting activities on wetlands. The relatively low reactivity of lead resulted in the accumulation and persistence of shot in the soils and sediments of wetlands and its subsequent ingestion by waterfowl. This exposure resulted in a variety of sublethal effects, reduced survival, and direct mortality. Bald eagles (Haliaeetus leucocephalus) and other raptors that fed on lead shot embedded in the tissues or present in the intestinal tract of waterfowl demonstrated acute and chronic symptoms of lead poisoning. The poisoning of bald eagles by lead shot was the impetus for the final decision to ban the use of lead shot for hunting waterfowl [8]. Although lead shot has been banned in the hunting of waterfowl in the United States since the 1991-92 hunting season, it continues to be used in a variety of other shooting activities, including upland game hunting and target shooting. An examination of the available literature reveals similarities between the current distribution and deposition of lead shot in intensively hunted upland habitats and those that were documented when waterfowl were hunted with lead shot. For example, in 1989, about 41.3 million mourning doves were harvested in the United States [9]. Lewis and Legler [10] estimated that five to eight shells were shot for each dove bagged. Therefore, approximately 200 to 330 million shells with lead shot were fired at mourning doves alone. Using an estimate of $28 \mathrm{~g}$ of lead per shell (approximately 1 oz.), a calculated 5.6 to 9.2 million $\mathrm{kg}$ of lead was introduced into terrestrial environments for the harvest of mourning doves annually. Totals associated with hunting of all upland game and target shooting in the United States would be much greater.

Furthermore, doves are commonly hunted over selected agricultural fields that are managed to provide food for doves; this results in deposition of shot in relatively confined areas. For example, one intensively hunted upland game area was shown to have 860,185 lead shot pellets/ha following the hunting season [11]. These intensively hunted fields are often the same areas where mourning doves and other avian species with similar foraging habits feed. As a result, the ingestion of lead shot can occur and has been documented in upland birds [12].

Recreational shooting, such as trap and skeet, is an increasingly common activity in the United States. In 1993, 8,000 public and private shooting ranges were present in the United States. Spent lead shot deposited at these ranges provides another potential source of exposure. At one range in New Jersey, an average density of 3.7 billion shot pellets/ha was recorded in the shot fall zone [13]. Some ranges that are the most heavily contaminated with lead might require a major clean-up. Although shooting ranges are typically in upland habitats, some are located near wetlands. Lead has been reported in surface water at some shooting ranges [13], but the effects of such inputs are beyond the scope of this risk assessment. Under the Toxic Substances Control Act (TSCA), the EPA has a responsibility to protect human health and the environment from ". . . toxic substances in toxic amounts." Additionally, the U.S. Fish and Wildlife Service (USFWS) under the Migratory Bird Treaty Act (MBTA) and the Endangered Species Act (ESA) has legal man- 
dates to protect populations of migratory birds and threatened and endangered species.

\section{Impacts from lead shot (stressor)}

The stressor of concern in this risk assessment is spent lead shot. Lead shot is discharged into the environment in substantial amounts during hunting of upland game and through a variety of target shooting activities. Elemental lead has been recognized as a toxic material for more than 25 centuries and its many modes of toxicologic action are well understood [14]. Lead is a cumulative metabolic poison affecting a large number of biological functions including survival, reproduction, growth and development, and behavior [14]. Its potential to induce lethal and sublethal effects in avian species, including waterfowl [5,15], raptors [16], and upland birds [17-19], has been documented previously.

Lead enters the environment through a variety of activities, including the burning of fuels containing lead and activities associated with the mining and refining of lead ore [20]. Total lead emission into the air in the United States in 1985 was 21,000 metric tons [21]. After being deposited in the environment, lead can be dissolved in an acidic setting and incorporated into a number of biotic components of the ecosystem. Another route of environmental lead deposition is by way of hunting and sport shooting activities. For example, during 1965 to 1971, the USFWS [8] estimated that between 2.2 and 2.7 million $\mathrm{kg}$ of spent lead pellets was deposited annually by waterfowl hunters and that the shooting of other migratory birds annually contributed an additional 13 million $\mathrm{kg}$ of lead pellets, largely in upland habitats.

Although acute effects of environmental lead on wildlife have been documented at a few localized sources (e.g., mining waste run-off, cf. [22]), most cases of acute effects from lead have been attributed to spent lead shot. In fact, during the last decade, numerous regulatory steps were enacted to reduce the deposition of lead in the environment (e.g., restricting the utilization of leaded fuels, reducing the allowed lead emissions, restrictions of lead-based products, and banning the use of lead shot for the hunting of waterfowl). However, lead shot continues to be used for hunting upland game and for other recreational shooting.

\section{Ecological endpoints}

Assessment. The goal of this assessment is to provide information necessary for the management of shooting ranges and designated upland hunting areas that will sustain healthy avian populations under a regime of recreational utilization. The risk assessment endpoint is healthy and sustainable avian populations in upland habitats. Mourning doves alone annually account for 10 million days of hunting recreation for 2.3 million hunters [9]. The mourning dove is an appropriate avian model for this risk assessment because it is likely to be exposed to spent lead shot in upland habitats and it has the potential to be affected by exposure to lead.

Measurement. The measurement endpoints selected for this risk assessment include estimates of exposure such as shot density (number of lead shot pellets/ha) in upland soils, prevalence of ingestion of lead shot by doves, lead levels measured in liver tissues, and known and/or anticipated toxic effects associated with the ingestion of lead shot based on results from laboratory studies. These variables were used to assess whether spent lead shot in shooting ranges and game lands presents an unreasonable risk either via widespread and repeated mortality or via sublethal
Conceptual Model for Tracking Stress Associated with Lead Shot Through Upland Ecosystems

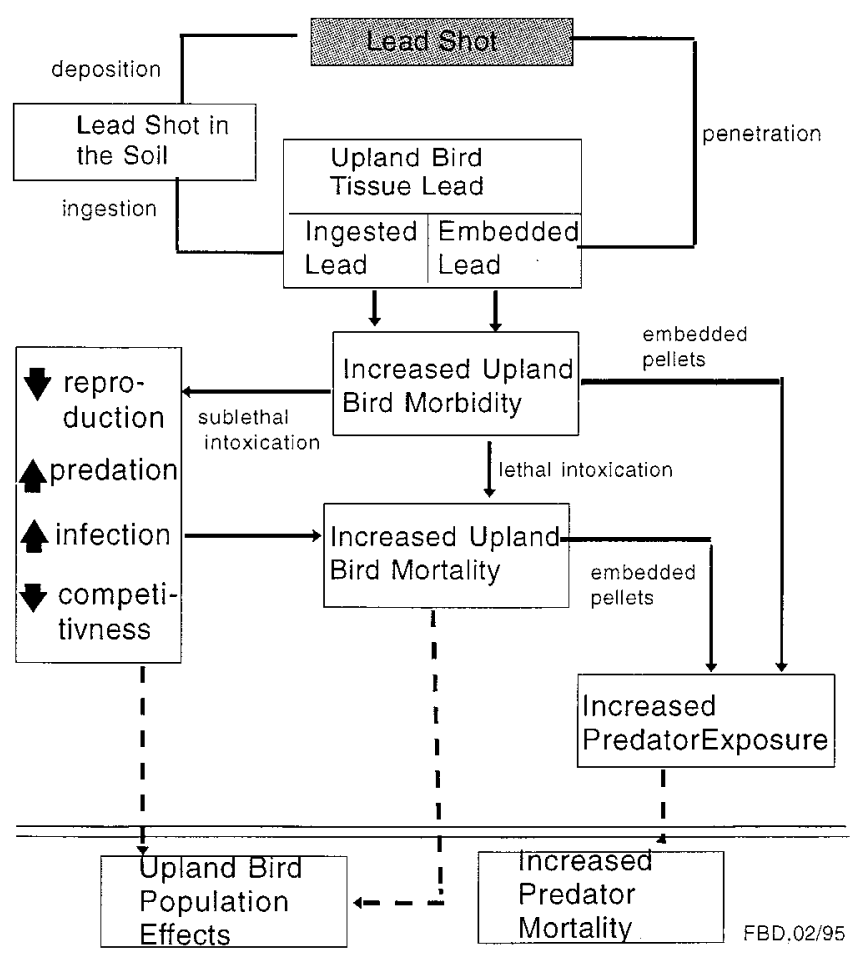

Fig. 2. Conceptual model for tracking stress associated with lead shot through upland ecosystems.

effects such as impaired reproduction [23]. The assessment was based on predictions from the results of controlled studies and field observations.

\section{Conceptual model}

Ecological impacts result from the interaction of the stressor, in this case lead shot, with the resource of concern (upland bird populations). A framework of the pathways involved in the flow of stress associated with lead shot to upland avian species illustrates the important concepts engendered in the conceptual model (Fig. 2).

Lead shot interacts with upland avian species via two exposure routes: through ingestion and through direct penetration of the shot into bird tissues. Both exposure pathways can occur for some upland avian species such as mourning dove, quail, and perhaps other species as well (see Analysis section).

Analyses of field and laboratory data indicate that the toxicologic consequences of lead shot ingestion are dependent on a number of variables (e.g., condition of the bird, climate, gender, age, and diet). As a result, two scenarios, with attendant toxicological effects, can be envisioned: (1) the ingested pellets might be eliminated (via regurgitation or passage through the gastrointestinal tract) before any significant dissolution or absorption of lead occurs; (2) the pellets may be partially or totally dissolved in the gizzard, resulting in the occurrence of a range of toxicologic effects over various temporal scales. These toxic effects have the potential to affect the health of upland game birds.

Birds injured but not killed during the hunt might carry varying amounts of lead shot, some of which remains embedded in their tissue. It is reasonable to assume that the survival of 
Table 1. Soil contamination with spent lead shot in upland game hunting areas

\begin{tabular}{|c|c|c|c|c|}
\hline Location & Habitat & $\begin{array}{l}\text { Shot density } \\
\text { (pellets/ha) }\end{array}$ & $\begin{array}{c}\text { Sample } \\
\text { depth } \\
(\mathrm{cm})\end{array}$ & Reference \\
\hline Illinois & $\begin{array}{l}\text { Cultivated fields }{ }^{\mathrm{a}} \\
\text { Cultivated fields }{ }^{\mathrm{d}} \\
\text { Woody fencerows } 75 \% \text {, }^{\mathrm{d}} \\
\text { corn stubble } 25 \%\end{array}$ & $\begin{array}{r}69,928^{\mathrm{b}} \\
180,875^{\mathrm{c}} \\
51,643 \\
136,150\end{array}$ & $\begin{array}{l}1.3 \\
1.3 \\
2.5 \\
2.5\end{array}$ & [27] \\
\hline Indiana & Cultivated fields ${ }^{\mathrm{a}}$ & $\begin{array}{c}0-8,608^{\mathrm{b}} \\
2,152-83,928^{\mathrm{c}}\end{array}$ & $\begin{array}{l}1.3 \\
1.3\end{array}$ & [28] \\
\hline New Mexico & Stock tank & $167,593-860,185$ & 1.3 & [11] \\
\hline Tennessee & Cultivated fields ${ }^{\mathrm{a}}$ & $\begin{array}{r}26,909^{\mathrm{b}} \\
107,637^{\mathrm{c}}\end{array}$ & $\begin{array}{l}0.95 \\
0.95\end{array}$ & [10] \\
\hline
\end{tabular}

${ }^{a}$ Managed for mourning doves.

b Prehunt.

c Posthunt.

${ }^{\mathrm{d}}$ Managed for put-and-take pheasant hunting.

these injured birds will depend on the amount of shot and on the intensity of the trauma produced on impact. Wounded birds may receive insignificant injuries, suffer significant nonfatal injuries with attendant morbidity (e.g., compromised locomotion), or succumb to trauma-induced mortality occurring immediately or shortly after injury. These birds become potential sources of lead ingestion for predators or scavengers (e.g., raptors or carnivorous mammals). Waterfowl that carry embedded lead shot were shown to be a cause of lead intoxication in eagles that consumed dead or dying birds [24,25].

\section{Hypothesis}

The major null hypothesis generated by this conceptual model is that the use of lead shot for both upland hunting and target shooting does not result in an unreasonable risk of repeated and widespread mortality or of impaired reproduction to exposed bird populations.

Four specific questions can be used to test the validity of this hypothesis. (1) Does the amount of lead shot deposited through hunting of upland game and target shooting result in a sufficient exposure to lead shot to make intoxication possible? (2) Do upland birds ingest potentially toxic amounts of lead shot? (3) Are avian predators exposed to lead shot through the consumption of upland avian prey with ingested or embedded lead shot? (4) If birds are exposed, do laboratory data support the prediction of sublethal effects, impaired reproduction, or direct mortality?

The following section examines these issues.

\section{ANALYSIS}

\section{Exposure}

The geographic distribution of spent shot in the United States is undoubtedly extensive, because there were an estimated 7.6 million small game hunters and 1.9 million dove hunters in 1991 [26]. Given the large amount of lead introduced into terrestrial habitats for the harvest of upland game and the geographic extent of this contamination, the potential exists for ingestion of lead shot by upland wildlife.

In the discussion that follows, we present the available data on (1) soil contamination on public upland hunting areas and on private target ranges, (2) ingestion of spent shot by upland game birds and their predators, and (3) lead concentrations in the livers of upland birds indicative of exposure to lead. We conclude with a discussion of the potential biases associated with the collection of the data presented.

\section{Soil contamination}

Detailed studies on the density of lead shot in upland habitats are limited compared to those for wetland habitats, and the available data are restricted mainly to fields managed for mourning dove hunting (Table 1). Data also are available for target ranges (Table 2), although some of the shot densities were measured in wetlands. We expect the latter values are not atypical of upland areas, because the shot density is likely affected by the number and arrangement of the shooting positions and the amount of ammunition used, irrespective of the presence of water in the shot fall area. This evidence indicates that significant quantities of lead shot are available to doves and other upland birds. The reported densities of shot in cultivated fields managed for dove hunting range from 2,152 to 180,875 pellets/ ha and from 136,150 to 860,185 pellets/ha in other habitats attractive to doves and other upland birds (e.g., water sources and fencerows; Table 1). Lead shot densities observed on some target ranges (up to 3.7 billion pellets/ha) appear to greatly exceed those for hunting areas.

Fields managed for dove hunting are often cultivated, resulting in the periodic redistribution of shot deeper into the soil. Under these conditions, shot densities may be much lower at the beginning of the hunting season, increasing greatly after hunting begins $[10,27,28]$. For example, shot densities in cultivated fields, where birds are hunted, have been shown to be 3 to 10 times greater after the hunting season and before cultivation than after the fields are tilled (Table 1). As a result, shot is most available in cultivated fields during the winter months. In addition, densities among fields may vary based on the size and shape of the field [28]. In contrast to game fields, the data on shot densities in other habitats are extremely limited [11] (Table 1).

Similar observations have been made in waterfowl habitats, where shot densities in upper sediment layers in uncultivated areas were significantly greater than corresponding densities in cultivated areas [29,30]. In addition, shot settled more slowly in wetland habitats with dense soils than in those with loose soils [5,31,32]. Settlement rates would presumably be even slower in terrestrial soils that are relatively more compact. Lead is relatively inert and, when deposited in the soil, is only slowly 
Table 2. Soil contamination with spent shot at shooting and target ranges

\begin{tabular}{lcccc}
\hline Location & Shot density & $\begin{array}{c}\text { Soil Pb } \\
\text { concn. }(\mathrm{mg} / \mathrm{kg})\end{array}$ & $\begin{array}{c}\text { Sample depth } \\
(\mathrm{cm})\end{array}$ & Reference \\
\hline U.S. (New Jersey) & $\begin{array}{c}1.32 \times 10^{6}- \\
3.70 \times 10^{9} / \mathrm{ha}\end{array}$ & $\mathrm{NR}$ & 7.5 & {$[13]$} \\
Denmark & $370 \mathrm{~g} / \mathrm{m}^{2}$ & $1,000^{\mathrm{a}, \mathrm{b}}$ & 5 & \\
& $531 \mathrm{~g} / \mathrm{m}^{2}$ & $274^{\mathrm{a}}$ & 9 & \\
& $830 \mathrm{~g} / \mathrm{m}^{2}$ & $615^{\mathrm{a}}$ & 8 & \\
Finland & $\mathrm{NR}^{\mathrm{c}}$ & $\bar{x}=27,000^{\mathrm{a}}$ & Humus layer & [98] \\
Netherlands & $\mathrm{NR}$ & $4,900-52,000$ & & {$[99]$} \\
\hline
\end{tabular}

a EDTA-extractable lead, shot removed.

${ }^{\mathrm{b}}$ Cultivated soil.

${ }^{\mathrm{c}}$ Not reported.

d Total lead.

transformed into various oxidized compounds. The relative nonreactivity of lead assures its longevity. Jorgensen and Willems [33] estimated that lead shot may persist for 100 to 300 years in undisturbed soils.

The shot densities reported in fields used for mourning dove hunting (Table 1) may not be representative of those associated with the hunting of other upland game. The number of shells expended per dove harvested [34] might exceed that used to kill other upland species. Likewise, dove hunting activities largely appear to be restricted to fixed locations within small areas attractive to doves (e.g., cultivated fields, fencerows, water sources).

\section{Direct ingestion of spent shot}

Like waterfowl, upland birds probably ingest spent shot by mistaking it for food [35,36] or grit [37-39]. There are also limited observations of mourning doves feeding shot to nestlings [40].

Most of the available data on the prevalence of shot ingestion in upland birds are from studies only on mourning doves. Mortality caused by lead shot poisoning has been reported in various localities for several other species, including northern bobwhite (Colinus virginianus: Florida, Illinois); scaled quail (Callipepla squamata: New Mexico); ring-necked pheasant (Phasianus colchicus: Nebraska, California, United Kingdom); wild turkey (Meleagris gallopavo: New York) (Table 3); Hungarian partridge (Perdix perdix: Denmark); sandhill crane (Grus canadensis: Wisconsin, Nebraska, Texas, Mississippi); and wood pigeon (Columbo palumbus: Denmark) [8,12,41]. A review of the data on mourning doves indicates lead shot ingestion rates (i.e., the fraction of birds found with one or more pellets in the gizzard) that range from 0.2 to $6.4 \%$. For studies with $n>410$,

Table 3. Prevalence of lead shot in gizzards of upland birds and cases of lead shot poisoning; average numbers of shot pellets in gizzards containing shot are given in parentheses

\begin{tabular}{|c|c|c|c|c|c|}
\hline Species & Location & $\begin{array}{c}\text { No. } \\
\text { of birds } \\
\text { collected }\end{array}$ & $\begin{array}{c}\text { No. } \\
\text { with lead } \\
\text { shot }\end{array}$ & $\begin{array}{c}\% \\
\text { Gizzards } \\
\text { with shot }\end{array}$ & Reference \\
\hline \multicolumn{6}{|l|}{ Prevalence of lead shot } \\
\hline \multirow{9}{*}{ Mourning dove } & Alabama & 521 & $5(1)$ & 1.0 & {$[100]$} \\
\hline & Illinois & $616^{\mathrm{a}}$ & $2(1.5)$ & 0.3 & W. Anderson, \\
\hline & & $521^{\mathrm{b}}$ & $19(1.8)$ & 3.6 & $\begin{array}{l}\text { unpublished } \\
\text { data }\end{array}$ \\
\hline & Maryland & 62 & $4(1.8)$ & 6.4 & [46] \\
\hline & Mid-Atlantic states & 412 & $10(1)$ & 2.4 & [101] \\
\hline & New Mexico & 420 & 1 & 0.2 & [11] \\
\hline & & & $15^{\mathrm{c}}$ & 3.6 & \\
\hline & Tennessee & 1,949 & $23(2.7)$ & 1.1 & {$[10]$} \\
\hline & Virginia & 35 & $1(1)$ & 2.9 & {$[102]$} \\
\hline Ruffed grouse & Virginia & 16 & 0 & 0 & [103] \\
\hline Rock dove & Maryland & 13 & $3(2)$ & 23 & [104] \\
\hline Marsh harrier & France & $214^{\mathrm{d}}$ & $26(1.1)$ & 12.1 & [45] \\
\hline \multicolumn{6}{|l|}{ Poisoning cases } \\
\hline $\begin{array}{l}\text { Northern bobwhite } \\
\text { quail }\end{array}$ & Illinois & 1 & $1(4)$ & Not applicable & [105] \\
\hline Scaled quail & New Mexico & 1 & $1(13)$ & Not applicable & [106] \\
\hline $\begin{array}{l}\text { Ring-necked } \\
\text { pheasant }\end{array}$ & California & 1 & $1(29)$ & Not applicable & [107] \\
\hline Wild turkey & New York & 1 & $1(4)$ & Not applicable & [108] \\
\hline
\end{tabular}

a First 2 days of hunting season on sunflower fields.

${ }^{b}$ After second day of hunting season.

${ }^{c}$ Includes birds with perforated gizzards containing lead shot.

${ }^{\mathrm{d}}$ Regurgitated pellets from roosts. 
Table 4. Percentage of upland birds with elevated liver lead concentrations associated with the use of lead shot; numbers in parentheses represent birds with potentially toxic concentrations

\begin{tabular}{|c|c|c|c|c|c|}
\hline Species & Location & $\begin{array}{l}\text { No. birds } \\
\text { collected }\end{array}$ & $\begin{array}{l}\text { No. with } \\
\text { elevated } \\
\mathrm{Pb} \text { levels }\end{array}$ & $\begin{array}{l}\% \text { with } \\
\text { elevated } \\
\text { liver lead }\end{array}$ & Reference \\
\hline \multirow[t]{5}{*}{ Mourning dove } & Illinois & $\begin{array}{l}616^{\mathrm{b}} \\
521^{\mathrm{d}}\end{array}$ & $\begin{array}{l}\mathrm{NR}^{\mathrm{c}}(2) \\
\mathrm{NR}(11)\end{array}$ & $\begin{array}{l}0.3 \\
2.1\end{array}$ & $\begin{array}{l}\text { W. Anderson, } \\
\text { unpublished } \\
\text { data }\end{array}$ \\
\hline & Maryland & 40 & $24(2)$ & $60(5)$ & {$[46]$} \\
\hline & Mid-Atlantic states & 412 & $21(\mathrm{NR})$ & 5.1 & {$[100]$} \\
\hline & New Mexico & 250 & $20(9)$ & $8(3.6)$ & [11] \\
\hline & Virginia & 35 & 1 & 2.9 & [101] \\
\hline $\begin{array}{l}\text { Diurnal raptors } \\
\text { (11 species) }\end{array}$ & France & 165 & $8(3)$ & $4.8(1.8)$ & [44] \\
\hline $\begin{array}{l}\text { Nocturnal raptors } \\
\text { (6 species) }\end{array}$ & & 57 & 0 & 0 & \\
\hline Marsh harrier & & 7 & $1(1)$ & $4.3(4.3)$ & [45] \\
\hline
\end{tabular}

between 0.3 and $3.6 \%$ of the gizzards examined contained ingested shot (Table 3). On cultivated fields, lead shot ingestion varies with the time of year, due to effects of cultivation on shot density or the proximity to hunting season. For example, data from Illinois (W. Anderson, unpublished data) show that shot ingestion in doves harvested on cultivated fields increased dramatically during the course of the hunting season, coincident with an increase in field shot density. In the studies summarized in Table 3, the majority of gizzards that contained any shot contained only a single lead pellet.

Note that $95 \%$ of the birds examined for the prevalence of lead shot in Table 3 were mourning doves, and $4.5 \%$ were marsh harriers (Circus aeruginosus). These data on shot ingestion by mourning doves may not be representative of other upland species. As with waterfowl, factors such as feeding habits [5] and grit type and size preferences, which vary with species [38,39], are likely to influence shot ingestion. Ingestion also might vary among locations because of differences in the availability of grit [36,38,39] or type of ground cover [42].

\section{Secondary ingestion of spent shot}

The potential for raptors, particularly bald eagles, to ingest lead shot expended during waterfowl hunting is well documented $[8,12,25]$. In contrast, few corresponding data for raptors predatory on upland birds exist. However, mortality of golden eagles (Aquila chrysaetos), red-tailed (Buteo jamaicensis) and rough-legged (Buteo lagopus) hawks, honey buzzards (Pernis apivorus) (in Europe), and prairie (Falco mexicanus) and peregrine (Falco peregrinus) falcons associated with the ingestion of lead shot, presumably in upland prey, has been reported [12]. In addition, bald eagles wintering near Provo, Utah, have been reported to ingest lead shot while feeding on black-tailed jackrabbits (Lepus californicus) [43]. Many raptors regurgitate the indigestible portion (bones, fur, feathers) of prey items in a form known as "pellets." Lead shot was found in $71 \%$ of the regurgitated pellets from this eagle population ( $>100$ birds). Shot also has been reported in a high proportion $(70 \%)$ of regurgitated pellets from golden eagles in Norway [44]. Likewise, recent examination of regurgitated pellets from marsh harriers in France indicated that $12 \%$ contained lead shot, in most cases one lead shot pellet per regurgitated pellet [45] (Table 3). Al- though this species is associated with wetland habitats in France and will prey on waterfowl, lead exposure in harriers from one of the marshes studied resulted mainly from the ingestion of crippled or unretrieved mammals [45]. Secondary ingestion of lead shot by marsh harriers increased as the hunting season progressed [45]. Secondary ingestion of lead through the consumption of lead-poisoned tissues of prey items has received less study; lead ingested in this manner would less likely be regurgitated.

\section{Lead concentrations in liver associated with} direct ingestion of spent shot

The liver lead criteria established by Pain et al. [45] were used to document and quantify the exposure of upland birds to spent shot. Birds were considered to be exposed to lead when the liver had $\geq 2 \mathrm{ppm}$ wet weight (equivalent to $6 \mathrm{ppm}$ dry weight). Physiological manifestations of lead poisoning can be present when liver lead levels reach $\geq 6$ ppm wet weight (20 ppm dry weight). These criteria were based on the data available from a variety of avian species [45]. These criteria are more protective than those proposed by Locke and Bagley [46], which would not confer protection in view of more recent data (reviewed by Pain et al. [45]) and a reexamination of data presented by the authors themselves [46,47].

Less information is available to quantify the exposure of upland birds to lead based on liver lead concentrations than is available from ingestion data (Table 3 ). Using the criteria above, the proportion of mourning doves exposed to lead ranged between 0.3 and $60 \%$, although the latter figure is based on a very small sample size. Similar to shot ingestion, liver lead levels appeared to increase during the hunting season (W. Anderson, unpublished data; Table 4). For surveys in which sufficient data were available $(n>250)$, the percentage of doves collected during the hunting season with potentially toxic levels of lead ranged from 2.1 to $5.1 \%$ (Table 4 ).

In a study of mourning doves in Illinois, there was a close correspondence between the prevalence of lead shot in the gizzards (Table 3 ) and the prevalence of liver lead concentrations indicative of lead poisoning ( $>6 \mathrm{ppm}$ wet weight; Table 4). In other studies, the prevalence of elevated liver lead concentrations, based on the lower criteria of exposure $(>2 \mathrm{ppm}$ wet 
weight), was greater than the prevalence of lead shot in gizzards. This observation is consistent with studies of waterfowl, where the presence of shot in gizzards is considered a conservative estimate of lead exposure [48] because lead pellets may be expelled following abrasion in gizzards (and subsequent absorption of lead into body tissues) and because animals might be exposed to other sources of lead. In such cases, liver lead concentrations would be elevated despite the absence of shot in the gizzard.

Moderately elevated liver lead concentrations $(>2$ but $<6$ ppm wet weight) might result, wholly or in part, from exposure to sources of lead other than spent shot. However, the percentage of mourning doves with lead shot in their gizzards is similar to the percentage of birds found to have potentially toxic lead concentrations in liver (Tables 3 and 4). Lead shot ingestion might be an important factor for elevated liver lead levels in mourning doves, but the data are circumstantial and the connection between lead shot and elevated liver lead levels clearly requires more investigation.

\section{Lead concentrations in liver associated with} secondary ingestion of spent shot

Data on lead concentrations in the livers of raptors that feed on upland game are limited. The most extensive survey, conducted in France [44], found that in 11 species of diurnal raptors, $4.8 \%$ of the 165 birds examined contained elevated levels of lead in livers ( $>2$ ppm wet weight), with $1.8 \%$ of the concentrations indicative of lead poisoning (Table 4). The authors attributed these findings of elevated lead to the prior ingestion of spent lead shot embedded in game animals. Comparable examination of six species of nocturnal raptors (57 individuals), which feed primarily on small mammals, did not detect elevated levels of lead in liver tissue [44]. In an examination in Denmark of 30 common buzzards (Buteo buteo), four had liver lead concentrations above $2 \mathrm{ppm}$ wet weight and one of these exceeded $6 \mathrm{ppm}$. All other raptors examined (21 individuals) had levels $<1.5 \mathrm{ppm}$ wet weight, except for one kestrel (Falco sparverius) in which the liver contained $2.3 \mathrm{ppm}$ [49]. Borg [50] reported liver lead concentrations of 10 and $36 \mathrm{ppm}$ wet weight in two golden eagles that died from lead poisoning in Sweden. In the United States, the species of primary concern are those like accipiters (e.g., northern hawk, Accipiter gentilis; Cooper's hawk, A. cooperii; sharp-shinned hawk, A. striatus) that feed on upland game birds.

Biases in assessing the exposure of upland birds to spent lead shot

There are several potential sources of error in the data presented that may affect estimates of exposure of upland birds to spent lead shot. Studies on waterfowl in the United States have shown that the proportion of hunter-killed birds with lead shot in their gizzards is 1.6 to 3.8 times higher than the proportion in researcher-collected birds [5,51], although Lumeij and Scholten [52] reported no collection bias for mallard ducks (Anas platyrhynchos) in the Netherlands. This suggests that lead-intoxicated birds are more susceptible to being shot during a hunt. At present, no data are available to address this potential collection bias with respect to upland birds exposed to lead shot. It should be noted that the great majority of mourning dove gizzards that contained lead shot had a single pellet. It is possible that as birds ingest two or more pellets they quickly become debilitated and therefore become increasingly less available to collection.
Because ingested shot is eventually eliminated from the gizzard by surviving birds, data on the presence of shot in the gizzard are only representative of the sampling period and underestimate exposure over the course of an entire year. In mallards, for example, Bellrose [5] calculated that survey data underestimated total annual exposure by a factor of six. Estimates of shot ingestion also may be influenced by the method used for gizzard examination. Montalban and Hines [53] reported that manual examinations of waterfowl gizzards fail to detect $24 \%$ of ingested lead shot compared to x-ray examinations. Similar results have been reported by Furness and Robel [54]. On the other hand, Anderson and Havera [48] reported that the prevalence of shot ingestion in some waterfowl species may be overestimated unless the gizzards and the shot therein are examined carefully to ascertain whether the pellets were shot into the gizzard lumen during hunting as opposed to being ingested. Unfortunately, it is difficult to determine to what extent, if any, shot ingestion data from the studies summarized in this paper have been influenced by these biases.

It is likely that a small proportion of the total mourning dove population in the United States frequents areas known to be high risk regions, such as shooting ranges and managed hunting areas. If, for example, $10 \%$ of the dove population uses high risk areas, and $3 \%$ of these birds are at risk of lead poisoning, then only $0.3 \%$ of the total population is at risk. Given the high reproductive potential of mourning doves, this level of risk might be inconsequential. An estimate of the percentage of the total population at risk will be essential for determining an appropriate management policy for lead shot.

In summary, substantial evidence indicates that mourning doves can be exposed to lead via direct ingestion of spent shot. However, we have no estimate of the proportion of the mourning dove population that is at high risk. Other upland birds with similar feeding habits may be similarly exposed, and cases of individual poisonings have been reported for other species. The limited data available for raptors indicate that some diurnal species that prey on game animals are exposed to lead via the ingestion of embedded shot, and cases of lead poisoning have been reported for several species. The extent to which these exposures result in avian mortalities is not certain at present because it is difficult to find dead or moribund birds in the field. The next section will review the evidence of the effects of these exposures to lead on upland birds.

\section{Effects of lead in avian species: general considerations}

Inorganic or elemental lead, the form present in lead shot, has long been recognized as a poisonous substance. The nature of lead toxicity has been well studied in both mammals and birds $[8,55,56]$. Lead is a broad-spectrum metabolic poison that produces toxic effects in a wide range of organs and tissues. A major mechanism of toxicity appears to be its ability to bind to proteins, particularly enzymes, and to alter their biological functions. Lead poisoning produces severe degenerative changes in the central nervous system (altered neurophysiological behavior, cerebral necrosis, and death), in the peripheral nervous system (various forms of paralysis), in the blood and blood-forming tissues (anemia and impaired synthesis of hemoglobin), and in the kidney (reversible and irreversible renal dysfunction). Lead toxicity has caused reproductive sterility, abortion, and both mortality and morbidity in neonates. Immune function also can be impaired by lead as shown both by dysfunction of specific components of the immune system (cellmediated and antibody-mediated immunity) and increased sus- 
ceptibility to bacterial and viral pathogens in animals sublethally poisoned with lead. In addition to these specific effects, chronic lead poisoning often induces loss of body weight, proceeding to general emaciation, particularly in birds [7,57]. This effect probably results from behavioral changes, partial paralyses, and less specific metabolic alterations.

The toxicity of ingested lead shot to birds in general, and particularly to waterfowl, is well documented and has been reviewed previously $[7,8]$. Ingested shot dissolves in the acid environment of the avian stomach (proventriculus and ventriculus or gizzard) and is absorbed into the bloodstream through the wall of the digestive system. In contrast, lead shot that becomes embedded in tissues of birds that are shot but not killed is not solubilized except when it penetrates into the lumen of the gizzard or proventriculus. Thus, ingested shot is the source of lead shot poisoning in game birds. However, embedded shot may represent a potential source of ingested shot for predator or scavenger species.

The toxicity of lead shot to birds is broadly predictable but is highly variable among individuals of a given species. This variability results, partially or entirely, from a combination of (1) chance events associated with the retention of lead shot in the digestive system; (2) species-specific factors that affect the dose actually absorbed from a shot pellet; (3) components in the diet that may affect lead dissolution and absorption; and (4) environmental conditions to which the bird must respond.

Studies with a wide range of bird species show that the time during which a lead pellet might be retained in the digestive tract is highly variable $[16,58]$ and may vary from a few hours to several weeks. In granivorous birds, shot pellets may be passed through the intestinal tract after a period of retention in the gizzard in a manner analogous to dietary grit. The retention time appears to be, in part, affected by the physical nature of the diet. In carnivorous birds, lead pellets often are regurgitated along with undigested materials such as bones and hair, but some may persist in the stomach or be passed through the intestinal tract. Thus, it is not possible to predict precisely the toxicity of a specific amount of lead shot to an individual bird because the actual dose of absorbed lead, and, consequently, the toxic effects, can vary considerably. A specific oral dose may produce toxic effects ranging from death to no measurable effect among individual birds.

Among species, there are differences in stomach acidity, and perhaps in other chemical aspects of the gastric environment and the degree of physical abrasion to which ingested lead pellets will be exposed. These differences also may affect the rate of release of soluble lead from ingested pellets and hence the actual dose of lead absorbed from a specified oral dose of lead shot.

Diet also can have a pronounced effect on the toxicity of ingested lead shot. In particular, high levels of protein and calcium have been shown to reduce lead toxicity, although the exact mechanism for each is not known [7]. More generally, diets composed of whole or cracked cereal grains, particularly corn, enhance the toxicity of lead shot compared to more balanced, nutritionally complete diets.

Environmental factors other than diet also must be considered when evaluating the toxic effects of ingested lead shot. Studies of birds orally administered lead and then exposed to warm versus cold environmental temperatures have demonstrated a greater susceptibility and mortality among those birds exposed to cold $[18,59]$. The mechanism of this interaction is not known and may involve the combined effect of simultaneous
Table 5. Mean (standard error) lead concentrations in livers of adult mourning doves dying from or surviving ingestion of \#8 lead shot pellets for 34 days $^{\mathrm{a}}$

\begin{tabular}{ccc}
\hline $\begin{array}{c}\text { No. } \\
\text { of shot } \\
\text { ingested }\end{array}$ & $\begin{array}{c}\text { Pb concn. } \\
\text { in surviving doves }\end{array}$ & $\begin{array}{c}\text { Pb concn. } \\
\text { in dead doves }\end{array}$ \\
\hline 0 & $0.47(0.10)$ & - \\
1 & $0.97(0.17)$ & $26.8(11.0)$ \\
2 & $6.83(3.20)$ & $29.8(6.70)$ \\
4 & $1.50(0.33)$ & $31.1(4.07)$ \\
\hline
\end{tabular}

${ }^{a}$ Concentrations are given in parts per million wet weight, converted from dry weight by division by 3 after data in Custer et al. [71]. Each experimental group contained 25 birds. Data are from Buerger et al. [18].

stressors [60], the direct toxic effect of lead on general metabolism, which compromises the birds' ability to respond to cold, or both. Regardless of mechanism, such data suggest that risk estimates based on laboratory studies in which birds are maintained under uniform and favorable environmental conditions and given nutritionally complete diets ad libitum are likely to underestimate the toxicity of lead shot compared to studies of wild birds.

In summary, lethal and sublethal poisoning from ingestion of lead shot has been reported in birds. Death has occurred only a few days after ingestion, but more commonly has occurred after a longer period of exposure during which birds often show a variety of signs of illness characteristic of chronic lead poisoning. Under conditions of sublethal poisoning, birds can display the same signs of intoxication but ultimately survive. Toxicity studies on the occurrence and nature of both lethal and sublethal lead poisoning are available for several terrestrial avian species and are discussed separately below.

\section{Lethal lead poisoning}

Mourning dove. Lethal lead poisoning has been produced in mourning doves under a variety of exposure scenarios. Buerger et al. [18] demonstrated that gavage administration of $0,1,2$, or 4 lead shot pellets per bird (\#8 size or approximately $70 \mathrm{mg}$ lead/pellet) to groups of 25 adult birds resulted in mortality rates of $0,24,60$, and $52 \%$, respectively, during a 34-day observation period. These birds were maintained on a $95 \%$ corn (maize) diet and were housed outdoors during the winter months in the southeastern United States. Temperatures below $0^{\circ} \mathrm{C}$ were recorded during the experiment. Concentrations of lead in livers from birds in this experiment are given in Table 5. The liver concentrations and mortality rates indicate that, although a uniform dose of shot was given, the dose of lead absorbed varied greatly among individuals. In a second experiment by the same authors, adult female doves were administered a single \#8 pellet by gavage but were maintained indoors at a constant temperature of $22 \pm 3^{\circ} \mathrm{C}$ and provided with a nutritionally balanced diet. Under these conditions, no mortality was observed in any of the dosed birds.

Castrale and Oster [19] administered 0, 1, 2, and 4 lead shot pellets (\#8) to groups of 10 adult mourning doves. These birds were maintained at 22 to $27^{\circ} \mathrm{C}$ and were fed a pelleted complete ration as well as seeds and grain. At the end of the 4-week observation period, the numbers of birds that died in the 0-, 1-, 2-, and 4-pellet groups were $1,1,1$, and 2, respectively. These data are similar to those of Marn et al. [61], who reported no mortality in doves given one \#8 shot pellet and observed over 
a 3-week period. This same result was obtained in groups of birds kept at $5^{\circ} \mathrm{C}$ and maintained on pelleted complete feed or a mixed-seed ration.

Ringed turtle-dove (Streptopelia risoria). This species commonly has been used as an experimental surrogate for mourning doves, with similar results. Kendall et al. [62] (see also [59,63]) observed death within 9 days in five of seven doves, which had been force-fed four \#6 shot pellets (approximately $100 \mathrm{mg}$ lead/ pellet), housed at $6^{\circ} \mathrm{C}$, and fed a cracked corn diet. No mortality occurred when similarly dosed birds were maintained at $21^{\circ} \mathrm{C}$. In a subsequent experiment, Kendall et al. [17] intubated birds with \#6 lead shot $(0,2$, and 4 pellets per bird) to groups of six doves maintained at warm temperatures and fed a balanced complete feed. No mortality was observed during the 2 -week observation period.

Gallinaceous birds. A variety of gallinaceous species has been used in studies of lead toxicity. Damron and Wilson [64] reported on the response of groups of bobwhite (12 adults per group) treated with 0,5 , or $10 \# 8$ shot pellets once a week or three times a week for 4 weeks. The mortality rates were $8 \%$ for groups receiving 0 or 5 pellets once per week, and 58, 67, and $92 \%$ for groups receiving 5 pellets three times per week, 10 pellets once per week, and 10 pellets three times per week, respectively. In a second experiment, these authors observed $10 \%$ mortality in groups of 10 -week-old bobwhite given five pellets per week for 6 weeks. No mortality was observed among control groups. In all these experiments, birds were housed indoors and fed a balanced complete feed.

In another study [65] (see also [66], groups of nine 2-monthold willow ptarmigan (Lagopus lagopus) were administered (via oral gavage) single doses of 0,3 , and 6 \#6 lead shot pellets. After 150 days of observation, two birds died in the two dosed groups.

Raptorial birds. Raptors of several species have been exposed experimentally to lead. Reiser and Temple [67] gave lead acetate ( $3 \mathrm{mg}$ lead/kg body weight), administered daily by gavage, to five red-tailed hawks, three rough-legged hawks, and one golden eagle for 30 weeks. Over the course of the experiment, eight of the nine birds exhibited clinical signs of toxicosis, including depression and anorexia, and four birds died.

Pattee et al. [16] exposed five bald eagles to 10 \#4 lead shot pellets (approximately $200 \mathrm{mg}$ lead/pellet). The birds were housed outdoors and were given 10 additional pellets after all 10 of the previous dose had been passed in feces or casts. Three birds died 10, 12, and 20 days after being dosed with the lead. One bird died at 125 days after being given doses of 30 and 26 shot pellets during the last 2 weeks. The fifth bird became blind and was killed after 133 days. Based on calculations from weight changes in pellets recovered during the experiment, the birds that died within 3 weeks of their first dose had been exposed to 19.4 to $42.3 \mathrm{mg}$ of dissolved lead, whereas the two surviving for 125 and 133 days had been exposed to 184.9 and $129.0 \mathrm{mg}$ of dissolved lead, respectively. The four eagles that died had mean liver lead concentrations of $16.6 \mathrm{ppm}$ wet weight. One eagle that was dosed but did not die had a mean liver lead level of $3.4 \mathrm{ppm}$ wet weight; this was in contrast to a control eagle with a liver lead concentration of only $0.4 \mathrm{ppm}$ wet weight. This experiment was conducted over a 10-month period (May to March) with only two birds receiving lead at any one time, but climatic conditions experienced by each bird during lead exposure were not reported.

Stendell [68] fed groups of three 1-year-old American kestrels either a single \#9 lead shot pellet (approximately $49 \mathrm{mg}$ lead/pellet) or a diet of shot-free flesh from lead-poisoned ducks containing 40.8 ppm lead daily for 60 days. Franson et al. [69] and Pattee [70] fed groups of 16 pairs of American kestrels lead powder at 0,10 , and $50 \mathrm{ppm}$ of their diet for a 5- to 7-month breeding period beginning in November. The birds were housed in outdoor pens. Custer et al. [71] fed American kestrels biologically incorporated lead in the form of flesh from lead-poisoned chickens (Gallus gallus). Diets were mixed to contain 0.5 to $448 \mathrm{ppm}$ dry weight of lead (approximately 0.17 to 149 ppm wet weight) and birds were exposed for 60 days. No leadassociated mortality occurred in any of these experiments with American kestrels. However, Hoffman et al. [72] observed high mortality in nestling American kestrels administered $625 \mathrm{mg} /$ $\mathrm{kg}$ metallic lead. Nestling growth was impaired at doses as low as $125 \mathrm{mg} / \mathrm{kg}$. Geometric mean liver residues were $3.5 \mathrm{ppm}$ wet weight at $125 \mathrm{mg} / \mathrm{kg}$ and $5.5 \mathrm{ppm}$ wet weight at $625 \mathrm{mg} / \mathrm{kg}$. This study presents the strongest evidence for food chain effects of lead poisoning.

\section{Sublethal poisoning}

A number of pathological conditions have been described in birds sublethally poisoned with lead or during the course of chronic poisoning that ultimately was lethal. The following discussion includes both these forms of sublethal or prelethal poisoning but is focused on studies that have evaluated effects on reproduction and body weight.

Mourning doves. Carrington and Mirarchi [73] reported on an experiment to examine the effect of lead exposure on doves under field conditions. The investigators administered oral doses of zero $(n=29)$ or one $(n=26)$ \#8 lead shot pellet to wildcaught doves. Birds were then fitted with radio-transmitters, released, and followed for 3 weeks. No difference in mortality was detected between control and lead-exposed groups. Predation accounted for all known dove mortality during the experiment. Mammalian predators were responsible for 7 of 11 predator-killed doves in the lead-exposed group, but 0 of 7 predator-killed birds in the control group. In contrast, avian predators accounted for four and six killed birds in the leadexposed and control groups, respectively. Castrale and Oster [19] reported significant losses of weight in doves that received oral doses of two or four \#8 lead shot pellets during the first 2 weeks after exposure. Buerger et al. [18] observed a $21 \%$ reduction in the hatchability of eggs laid by doves given a single \#8 shot pellet over a 10-month breeding season. Males were not exposed to lead in this experiment. The reduction in hatchability was attributed to abnormally high rates of embryo death during the first 9 days of incubation.

Ringed turtle-dove. Testicular atrophy was reported by Veit et al. [63] (see also [62]) in groups of seven male doves given four \#8 lead shot pellets and kept at either 6 or $21^{\circ} \mathrm{C}$ for 9 days, and there was histological evidence of the degeneration of seminiferous tubules. In contrast, Kendall et al. [17] observed no significant changes in body weight in doves given two or four \#6 shot pellets and observed for 2 weeks.

Gallinaceous birds. Damron and Wilson [64] reported on a variety of lead-induced sublethal effects observed in a series of experiments with bobwhite quail. Birds given lead shot tended to lose body weight relative to controls, but statistical tests of differences were not significant, possibly a result of high variability in response. Various indices of semen quality in birds given 500 to $1,500 \mathrm{ppm}$ lead acetate in the diet did not differ from those of controls; however, immature birds receiving 2,000 and 3,000 ppm lead in the diet did exhibit lower weight gain 
and food consumption than controls. Similarly, Beyer et al. [57] reported weight loss proceeding to emaciation in bobwhite exposed to increasing concentrations of dietary lead acetate for several weeks. McConnell [58] reported large losses of weight in bobwhite fed lead shot at a variety of doses. In the latter study, birds that died of lead poisoning had lost an average of $36 \%$ of body weight by the time of death; however, sublethally poisoned birds, which lost weight, regained it when lead exposure was discontinued. The fertility and hatchability of eggs from birds that received 1 to 4 \#6 shot pellets or 15 to 100 \#6 or $\# 7^{1} \frac{1}{2}$ shot pellets were qualitatively lower than in eggs from controls; however, no statistical analysis was applied to these data.

Fimreite [65] (see also [66]) reported abrupt reductions in food intake and rapid emaciation in willow ptarmigan (Lagopus lagopus) given three or six \#6 shot pellets. Likewise, Morgan et al. [74] observed an $80 \%$ reduction in testicle weights in Japanese quail (Coturnix coturnix) given 1,000 ppm lead as lead acetate in their diet. The authors concluded that this represented a case of delayed development rather than degeneration or permanent damage because the quail were immature at the start of lead administration. Edens et al. [75] exposed male and female Japanese quail to 0 to $1,000 \mathrm{ppm}$ lead acetate in feed during the period from hatching to maturity at 12 weeks of age and observed reduced egg production in birds that received $1 \mathrm{ppm}$ lead or more; sexual maturity was delayed in females exposed to $10 \mathrm{ppm}$ or more of lead. The hatchability of eggs was reduced by 28 and $95 \%$ in groups exposed to 100 and 1,000 ppm lead, respectively. Mature body weight was not affected in males, but a $21 \%$ reduction was observed in females exposed to 1,000 ppm.

Mazliah et al. [76] orally administered lead acetate daily to 12 adult domestic chickens over a 3-year period and observed no weight loss or retarded growth. The lead-exposed hens laid considerably more eggs than did controls and egg shells and yolks had a high lead content. Testicular atrophy occurred in roosters, but fertility and hatchability of eggs were not assessed.

Raptorial birds. Pattee et al. [16] reported weight losses of 16 to $23 \%$ in bald eagles ingesting lead shot and Reiser and Temple [67] made similar observations of other diurnal raptor species given lead as lead acetate. Likewise, Beyer et al. [57] reported progressive emaciation in screech owls (Otus asio) given lead acetate at increasing doses; however, Pattee [70] found no lead-related effects on number of eggs laid, incubation, fertility, or eggshell thickness in American kestrels. These results agree with those of Custer et al. [71], who reported no significant lead-related changes in body weights or red blood cell parameters, and Stendell [68], who reported no sublethal effects. Hoffman et al. [77] administered 10 \#4 lead shot pellets to bald eagles. Effects observed included anemia, severely depressed amino leuvalinic acid dehydratase (ALAD), and enzyme changes indicative of liver and kidney injury. In a separate study, Hoffman et al. [78] administered metallic lead as found in lead shot orally to nestling American kestrels. Hematological alterations were more severe in nestlings than those reported elsewhere for adults. Anemia and biochemical alterations in the brain, liver, and kidney were found when doses exceeded 125 $\mathrm{mg} / \mathrm{kg}$.

\section{Characterization of a dose-response profile}

Only a few studies have established a dose-response relationship for lead shot toxicosis. Furthermore, these studies employed a variety of environmental, nutritional, and design pa- rameters that further complicate evaluation of inter- and intraspecies sensitivity to lead shot ingestion. However, some relationships between the number of lead shot pellets ingested and critical factors contributing to susceptibility to lead poisoning in doves and gallinaceous species have been characterized.

Diet. Diet strongly influences the effects of ingested lead shot and in some situations may be extremely influential in determining toxicological response in waterfowl. A similar effect of diet quality on susceptibility to lead poisoning has been suggested for doves $[18,61,79]$. However, the established relationship between dietary deficiencies in protein, calcium, and phosphorus (e.g., corn diets) and enhanced susceptibility to lead toxicosis documented in waterfowl species [80,81] is less obvious in these upland birds. Dietary stress also affects lead retention and absorption in mourning doves but appears to increase lethality of lead shot exposure only in combination with other environmental stressors $[18,61,79]$.

Ambient temperature. Mourning doves-Cold stress also is a very important factor affecting mourning dove susceptibility to lead shot poisoning. Buerger et al. [18] showed that ingestion of even a single \#8 shot pellet ( $\sim 70 \mathrm{mg}$ lead) during cold ambient temperature resulted in mortality (24\%) of mourning doves, and exposure to two or more \#8 pellets produced severe body weight loss and the death of more than half of treated birds. These data suggest that the probable LD50 for wild doves maintained at ambient conditions during fall and winter months would be between 140 and $280 \mathrm{mg}$ lead (equivalent of two to four \#8 shot pellets), and $90 \%$ of the deaths in this outdoor study occurred when temperatures dropped to $0^{\circ} \mathrm{C}$ [18]. Similarly, McConnell [58], studying mourning doves maintained outdoors, observed greater mortality $(72 \%)$ in birds dosed with \#71/2 lead shot during September to March than in doves dosed during summer months (13\%). It would appear from these limited data that exposure to $\geq 140 \mathrm{mg}$ of lead from pellets could produce significant mortality of mourning doves during periods of cold weather. Exceptions to this cold-lead synergism have been reported. Castrale and Oster [19] observed that mourning doves maintained at 21 to $27^{\circ} \mathrm{C}$ and dosed with four \#8 shot pellets (280 mg lead) exhibited only $20 \%$ mortality. One death also was recorded among 10 birds dosed with a single \#8 shot pellets ( $\sim 70 \mathrm{mg}$ lead), but no deaths were reported for the twopellet (140 mg lead) dose. In another study, Marn et al. [61] found no mortality in doves dosed at 5 or $22^{\circ} \mathrm{C}$.

Galliformes-The minimum dose for bobwhite quail described by Damron and Wilson [64] that adversely affected body weight gain was five \#8 shot pellets per week for 4 weeks $(\sim 350$ $\mathrm{mg}$ lead/week), which produced an $18 \%$ decrease in body weight but no mortalities in 10- to 16-week-old bobwhite quail. A mortality rate of $10 \%$ was observed when this exposure was continued for an additional 2 weeks. Exposure of young bobwhite quail to 15 \#8 shot pellets per week for 4 weeks (60 shot, $4,200 \mathrm{mg} \mathrm{lead})$ or 30 shot pellets per week for 4 weeks (120 shot, $8,400 \mathrm{mg}$ lead) resulted in 58 and $92 \%$ mortality, respectively. When exposed to outdoor conditions at the Arctic Wildlife Station in Trmso, Norway, winter grouse (Lagopus lagopus) exhibited lead toxicosis and mortality at much lower doses of lead pellets (one to six \#6 shot pellets) [66] than the bobwhite quail mentioned above. Thus, cold winter weather stress in combination with one or two lead shot pellets ( $>140 \mathrm{mg}$ lead) may well present a significant level of risk and an appropriate level of concern for galliform birds.

Raptors-Data for making a general estimate of what con- 
stitutes a hazardous lead exposure in raptors are insufficient. Although studies of lead toxicosis have been conducted with several species (e.g., American kestrels, various hawks and eagles), little of this information can be interpreted directly in terms of lead shot equivalents. Two studies that did address lead shot exposure in raptors $[16,68]$ did not provide sufficient data to estimate an effect threshold. For example, estimation of raptor sensitivity was limited to comparing potential exposure to 10 \#4 lead shot pellets. This exposure resulted in lethality in some bald eagles if the pellets were retained in the digestive tract [16]. Exposure to one \#9 shot pellet per day resulted in no lethal or sublethal effects in American kestrels [68].

\section{Sublethal effects}

Currently, only one study has documented an impact of lead shot ingestion on reproduction of upland birds. In this study, the administration of a single \#8 shot pellet $(\sim 70 \mathrm{mg}$ lead) resulted in increased early embryonic death and reduced hatchability ( $26 \%$ over 8 months) in mourning dove eggs [18].

Other sublethal effects reported for lead shot-exposed birds include changes in ALAD activity and other related hematologic parameters. However, it is unclear if adverse toxicological effects can be associated with decreased ALAD activity in the absence of anemia, which has only rarely been reported in lead shot-exposed birds [17].

\section{Summary}

The dose-response profile of lead shot toxicosis in non-waterfowl species has been poorly delineated. However, the information available can be used to estimate a threshold exposure level that may result in mortality of doves and galliforms. This threshold would seem to be lower during cold conditions and when birds have dietary deficiencies. Reproductive impairment has been demonstrated following exposure to a single spent lead pellet. Other sublethal effects were not consistently reported or quantified. Use of liver lead values in estimating exposure and severity of effect in upland birds should be considered conservative as they appear to underestimate exposure.

Ecological response analysis: Effects of lead shot on upland birds. Relation between the stressor and the ecological effects. Ecological response analysis is critical to the development of the Risk Characterization [1]. The following discussion relates to the assessment and measurement endpoints presented in the Problem Formulation. As noted, the assessment endpoint is healthy and sustainable avian populations in upland habitats. To evaluate the assessment endpoint, we propose several measurement endpoints: the density of lead shot in soils; the prevalence of ingestion of lead shot; the lead levels in liver tissues of exposed birds; and the results from laboratory and field studies of the effects of ingesting lead shot. These four endpoints relate to the overall issue of concern: the regulatory benchmark of widespread and repeated mortality.

The issues considered in this risk assessment for exposure to lead shot are in some ways more clearly defined because the endpoint of concern is primarily mortality. Although data are generally equivocal, the evidence indicates that in some species, e.g., mourning doves, the level of mortality associated with even small doses of lead shot can be substantial. Buerger et al. [18] showed that $24 \%$ of the birds treated with one \#8 lead shot pellet died and the LD50 estimated in this experiment was approximately two \#8 pellets. These data were collected from birds on a grain (95\% corn) diet in the winter. Data collated and presented earlier in this document suggest that a dose of 440 $\mathrm{mg}$ of lead pellets of any size may result in greater than $50 \%$ mortality in doves (data compiled on mourning doves and ringed turtle-doves). This is equivalent to a dose of two \#4 pellets or four \#6 pellets. Data collected on cold-stressed birds dosed with lead show higher mortality than in nonstressed birds. Although the studies vary in their methodology, some data suggest that the lethal dose could be less than half that reported above. Therefore, high levels of mortality can result from very low doses of lead under certain stressful conditions that could be observed in free-ranging birds.

The potential for exposure to lead shot can be extremely high in the habitats of concern, such as state game lands and hunting preserves. These areas contain habitat, natural or managed, that is conducive to maintaining high densities of upland game bird populations. Studies show that lead shot densities on these areas can be as high as 860,185 pellets/ha (Table 1) and soil lead levels can reach $70,000 \mathrm{mg} / \mathrm{kg}$ of soil (Table 2). These are clearly the worst case scenarios, however, and, in addition, the assumption is made that doves and other birds are feeding on the shooting ranges.

Some studies suggest that low levels of exposure might impair certain aspects of behavior and the hatchability of eggs. Buerger et al. [18] obtained a $26 \%$ reduction in hatchability of eggs from female doves exposed to a single \#8 lead pellet. These females were neither cold stressed nor subjected to low protein diets. Sublethal effects are often afforded less concern than mortality, but additional data might reveal this to be a more serious problem than is currently perceived. This is certainly an area in need of further study.

As an index of potential exposure, we reviewed the literature for estimates of the prevalence of lead shot in the gizzards of upland game birds, primarily mourning doves (Table 3). Although estimates from small sample sizes can be quite high, a conservative estimate of approximately $3 \%$ appears reasonable (Table 4). Data also were summarized on the percentage of upland birds with elevated liver lead concentrations associated with lead shot use (Table 4). Approximately $3 \%$ of the birds examined had elevated liver lead levels. These were not necessarily the same birds as those with lead shot in the gizzards, as discussed previously. If all mourning doves with lead shot in the gizzards develop elevated lead levels in the liver, and there are no additional birds that accumulate lead, then approximately $3 \%$ of the mourning doves in the high-risk areas in the United States are at risk of lead poisoning. The percentage could be higher if the presence of lead in the gizzards is a shortterm phenomenon. The mourning dove population in North America is estimated to be 450 to 500 million birds [82]. Depending on the proportion of the mourning dove population that occurs and feeds in high-risk habitats, several million birds could potentially be at risk. No current data indicate what this figure might be, nor is similar information available for upland birds other than doves.

The characterization of sublethal effects of lead shot exposure will require more experimentation and data to assess its risk to upland bird populations. Nevertheless, for mourning doves, the combination of cold susceptibility of lead-dosed birds and the progressively increasing incidence of shot ingestion during the course of the hunting season suggests that there is a risk of mortality to mourning doves in high-risk habitats during the fall or winter months. The discussion below focuses on the factors related to the estimation of population-level effects attributable to mortality caused by exposure to lead in shot. 
Monitoring of populations at risk: Seeking patterns for cause and effect relationships

Several endpoints can be monitored to evaluate populations potentially at risk. We discuss the scientific value of each and then present data on population trends.

Toxicological endpoints such as lead levels in blood, bone, liver, or other tissues provide information on the level or frequency of exposure. For these data to be of use in the risk assessment process, levels would have to be explicitly linked to some pathological outcome of interest (e.g., depressed reproductive success or mortality). The information currently available was derived largely from laboratory experiments, and proportionally fewer data were derived under field conditions. Furthermore, the link between these toxicological endpoints and mortality is not clearly established even under laboratory conditions.

In the field, mortality data are obtained primarily from direct counts of dead animals attributable to lead shot exposure. Although this would provide the most direct evidence of an impact, at least at the level of individuals in the population, mortality data are notoriously difficult to obtain [83]. If the objective is to construct a population risk assessment, mortality data of high quality, collected in a similar manner at all sites and consistent across sites and regions, would be required [84]. The criterion of unacceptable risk of widespread and repeatable mortality (the suggested endpoints of this risk assessment) does not require demonstration of a population-level effect over time, and as a consequence some of the requirements above can be relaxed. Widespread and repeatable mortality does not necessarily translate into long-term declines in population density, however, and from a management perspective, it would be difficult to justify the cost of regulating a stressor that has no population-level effects. Thus, data on long-term trends on population numbers are necessary from a risk management perspective.

Several large databases are available that track population trends in birds in North America. These include the Christmas Bird Survey, the Breeding Bird Survey, state agency surveys of upland game species, and USFWS surveys of game species. Such surveys present fairly reliable information on the long-term status of populations but do not provide cause and effect information. They can alert researchers to populations at risk, but other data are necessary to determine proximate causes for population-level changes [85]. In addition, surveys do not in any way allow for the extrapolation of these trends into the future.

Additional aspects of these data sets merit caution in interpretation. Using large databases of highly variable field observations to detect small changes over large spatial scales and long temporal scales makes ecological risk assessments difficult. Power of statistical tests will be weak because of small sample sizes or few replications. Theoretical scientists evaluate the truth of hypotheses and environmental risk assessors evaluate both the truth of hypotheses and the acceptability of risk decisions, which involve policy as well as science. The policy component can be substantial. A three-value decision-making process (accept, reject, no decision [86]) allows investigators to conclude no decision pending a request for more information or inclusion of more issues in the study. This also allows for the accumulation of information over time and the subsequent readjustment of probabilities clearly relevant to the risk assessment process [87].

Several recent studies have demonstrated declines in breeding populations of mourning doves in some regions [82,88,89]. During the past 10 years in the contiguous 48 states, populations have exhibited long-term, but nonsignificant, trends of decline in
Table 6. Trends in the number of mourning doves in the Western Management Unit [82 ${ }^{\mathrm{a}}$

\begin{tabular}{lcc}
\hline State & $1966-1994$ & $1985-1994$ \\
\hline Arizona & $-\mathrm{NS}$ & $-\mathrm{NS}$ \\
California & $-*$ & + NS \\
Idaho & $-\mathrm{NS}$ & $+*$ \\
Nevada & $-*$ & $-*$ \\
Oregon & $-\mathrm{NS}$ & $+\mathrm{NS}$ \\
Utah & $-\mathrm{NS}$ & $+\mathrm{NS}$ \\
Washington & $-\mathrm{NS}$ & $-\mathrm{NS}$ \\
\hline
\end{tabular}

${ }^{a}$ Hunting is permitted in all states. Results show the direction of the population trend $(+=$ increase, $-=$ decrease $)$ and the level of significance $(*=$ significant at $p<0.05$, NS $=$ not significant $)$.

21 states and significant declines in 4 states. During the same period, 13 states showed trends of increase and 10 exhibited significant increases. Twelve states do not allow hunting of mourning doves: Minnesota and Iowa in the Central Management Unit; and Maine, New Hampshire, Vermont, Massachusetts, Connecticut, New York, New Jersey, Ohio, Michigan, and Wisconsin in the Eastern Management Unit. In these states, mourning doves are classified as nongame birds.

In the Western Management Unit, all seven states (all of which are hunting states) had declining populations over the past 30 years (Table 6), although the data were statistically significant in only two states. The data on trends over the past 10 years suggest that the declines might be arrested, with one state (Nevada) showing statistically significant increases. Data from the Central Management Unit (Table 7) show 10-year declines for nine states (only one is significant) and increases for five states (none significant). Twelve of the 14 states allow hunting and eight of the declines, including the statistically significant decline, were in hunting states. There are 17 hunting states in the Eastern Management Unit and 10 nonhunting states (Table 8). The 10-year trends show declines in 10 of 17 hunting states (two significant) with increases (two significant) in the other 7 states. Only 3 of 10 nonhunting states showed declines (none significant), whereas 7 , all statistically significant, showed 10 -year increases. Over the past 10 years, 21 of 36 hunting states have trends of decline,

Table 7. Trends in the number of mourning doves in the Central Management Unit [82] ${ }^{\mathrm{a}}$

\begin{tabular}{lcc}
\hline State & $1966-1994$ & $1985-1994$ \\
\hline Hunting & & \\
Arkansas & $-\mathrm{NS}$ & $+\mathrm{NS}$ \\
Colorado & $+\mathrm{NS}$ & $-\mathrm{NS}$ \\
Kansas & $+\mathrm{NS}$ & $+\mathrm{NS}$ \\
Missouri & $-*$ & $-\mathrm{NS}$ \\
Montana & $-*$ & $-*$ \\
Nebraska & $-\mathrm{NS}$ & $-\mathrm{NS}$ \\
New Mexico & $+*$ & $-\mathrm{NS}$ \\
North Dakota & $+\mathrm{NS}$ & $-\mathrm{NS}$ \\
Oklahoma & $-\mathrm{NS}$ & $-\mathrm{NS}$ \\
South Dakota & $+\mathrm{NS}$ & $+\mathrm{NS}$ \\
Texas & $+\mathrm{NS}$ & $-\mathrm{NS}$ \\
Wyoming & $-\mathrm{NS}$ & \\
Nonhunting & & NS \\
Iowa & $-\mathrm{NS}$ & $-\mathrm{NS}$ \\
Minnesota & $-\mathrm{NS}$ & \\
\hline
\end{tabular}

a States are grouped by those that allow and prohibit hunting. Results show the direction of the population trend $(+=$ increase, $-=$ decrease) and the level of significance $(*=$ significant at $p<0.05$, NS $=$ not significant). 
Table 8. Trends in the number of mourning doves in the Eastern Management Unit [82 ${ }^{\mathrm{a}}$

\begin{tabular}{lcl}
\hline State & $1966-1994$ & $1985-1994$ \\
\hline Hunting & & \\
Alabama & $+\mathrm{NS}$ & $-*$ \\
Florida & $+\mathrm{NS}$ & $-\mathrm{NS}$ \\
Georgia & $-\mathrm{NS}$ & $-\mathrm{NS}$ \\
Illinois & $+\mathrm{NS}$ & $+*$ \\
Indiana & $-\mathrm{NS}$ & $+\mathrm{NS}$ \\
Kentucky & $-\mathrm{NS}$ & $-\mathrm{NS}$ \\
Louisiana & $+\mathrm{NS}$ & $+\mathrm{NS}$ \\
Maryland and Delaware & $-\mathrm{NS}$ & $-\mathrm{NS}$ \\
Mississippi & $-\mathrm{NS}$ & $-\mathrm{NS}$ \\
North Carolina & $-\mathrm{NS}$ & $-\mathrm{NS}$ \\
Pennsylvania & $+\mathrm{NS}$ & $+\mathrm{NS}$ \\
South Carolina & $-\mathrm{NS}$ & $-*$ \\
Tennessee & $-\mathrm{NS}$ & $+\mathrm{NS}$ \\
Virginia & $-*$ & $-\mathrm{NS}$ \\
West Virginia & $+*$ & $+\mathrm{NS}$ \\
Nonhunting & & \\
Michigan & $+\mathrm{NS}$ & $-\mathrm{NS}$ \\
New England & $+*$ & $+*$ \\
New Jersey & $-\mathrm{NS}$ & $-\mathrm{NS}$ \\
New York & $+\mathrm{NS}$ & $-\mathrm{NS}$ \\
Ohio & $-\mathrm{NS}$ & $+*$ \\
Wisconsin & $+*$ & $+*$ \\
\hline
\end{tabular}

${ }^{a}$ States are grouped by those that allow and prohibit hunting. Results show the direction of the population trend $(+=$ increase, $-=$ decrease) and the level of significance $(*=$ significant at $p<0.05$, NS $=$ not significant).

${ }^{\mathrm{b}}$ Maryland and Delaware were combined.

${ }^{\mathrm{c}}$ Maine, New Hampshire, Vermont, Massachusetts, Connecticut, and fRhode Island were combined. All are nonhunting states except for Rhode Island. See Dolton [82] for explanation of methodology.

with 4 states showing significant declines. Only 4 of 12 nonhunting states show declines, none significant; the remaining 8 states have increasing populations, and 7 of these are statistically significant.

One must be careful not to assume that these survey data implicate hunting as the single causal factor in the decline of mourning dove populations. Indeed, Geissler et al. [90] conducted a nationwide study of the impact of hunting on nesting mourning doves. There were no significant differences in the survival rates of either eggs or fledglings between hunted and nonhunted zones. There are many other confounding factors that differ between hunting and nonhunting states. For example, the nonhunting states are located farther north than most of the hunting states. Severe winter weather in the northern states during the 1970s might have been responsible for reducing the northern populations of mourning doves. The recent increases in mourning dove numbers in those states (many nonhunting) might only be a result of milder winters. This is apparently the case for other species of shortdistance migrant birds, for example, the eastern bluebird (Sialia sialis). Other factors that affect mourning dove populations include habitat loss and farming practices. The manner in which these factors vary by state and by region has not been evaluated. The degree to which all these factors, and their interactions, affect dove populations has not been studied. Although population-level effects are of paramount importance in a risk assessment, it is extremely difficult to obtain population-level data that can provide clear cause and effect links.

Concern is growing over the transfer of toxic substances through the food web $[91,92]$. Few data are available on the indirect exposure of predators to lead shot, but the known risk to bald eagles of lead shot embedded in waterfowl consumed by the eagles strongly suggests that this scenario be studied further in avian predators of upland game birds.

Data implicating aspects of hunting in the decline of mourning dove populations are not strong. However, the high toxicity of lead shot, its known lethality, possible effects on reproduction, and the high level of potential exposure of upland game birds to lead shot all argue for consideration of lead shot as an additional risk factor in the decline of mourning dove populations. Potential negative effects on populations of raptors and game and nongame birds also merit further study.

The ecological response analysis is a three-stage process. First, it is important to obtain estimates of the proportion of the populations of the species of concern that is at risk. Second, one must obtain evidence of widespread and repeatable mortality in these populations as a result of exposure to the stressor. Third, the widespread and repeatable mortality should be linked, in a cause and effect relationship, to data on long-term declines in population.

\section{RISK CHARACTERIZATION}

There is substantial information documenting lead toxicosis resulting from ingestion of lead shot. These data, coupled with data on potential avian exposure and field prevalence data, suggest the need to consider reduction of these types of exposure to lead shot and their attendant risks in the terrestrial environment. If the major criterion for risk assessment is the established policy standard of ". . . the likelihood of widespread and repeated mortality" (Ciba-Geigy v. EPA, 1989-874F.2d 277, 5th Cir. 1989; see also related policy statement, the Diazinon Remand Decision, EPA, July 12, 1990), then lead shot associated with some hunting activities in upland ecosystems merits additional study as a possible risk to mourning doves.

Population-level impacts are universally considered significant ecological effects and are important considerations under many resource management statutes, including hunting regulations. However, uncertainties associated with the measurement and verification of population effects due to environmental risks make these endpoints difficult for use in regulatory decisions at the present. There are numerous uncertainties.

The assessment of population effects requires high-quality mortality data or observations of reproductive effects in the field to generate either predictive or retrospective (impact) risk assessments. Sick or wounded birds seek cover and become subject to increased predation [93]. Carcass searching is unreliable, and a confirmation of numbers of moribund or dead birds generally is not possible. Even when reliable data have been obtained on avian mortality, models generally have not been able to predict population trends in response to environmental risks [94,95]. This is thought to be a result of the complex array of environmental and physiological factors influencing populations under field conditions.

Although the data implicate lead shot in mourning dove mortality in laboratory settings and in local areas of high risk in the field, the risk assessment is at its weakest when extrapolating these effects to the state, regional, or national level.

\section{Summary of exposure data}

The geographic distribution of spent lead shot in the United States is extensive; in addition, the use of shooting ranges and trap shooting is rising, thereby increasing both the number of lead exposure sites and the density of lead shot at each site. Exposure increases during the winter months, after the fall hunt- 
ing season. Lead shot becomes incorporated into the soil during spring cultivation, which is designed to increase cover vegetation and attract upland birds.

Upland birds ingest spent lead shot by mistaking it for food or grit. Embedded shot in wounded birds becomes available to raptors and other predators through secondary ingestion. Substantial evidence exists for the potential exposure of mourning doves to lead shot via ingestion. Field evidence for exposure resulting in death is not strong because of the inherent difficulties in finding dead or moribund birds in the field. In addition, the proportion of birds at high risk of exposure is not known.

\section{Summary of ecological effects}

Lead is a broad-spectrum metabolic poison that produces toxic effects in a wide range of organs and tissues. Effects are both lethal and sublethal and include immune system, behavioral, and reproductive anomalies. Ingested shot breaks down under the acid conditions of the gut. Lead shot embedded in tissue (e.g., from hunting) does not dissolve but may be a source of poisoning if ingested by a predator.

The toxicity of lead shot to birds is broadly predictable but highly variable among individuals of a given species. This variability in response is a result of a combination of (1) retention versus regurgitation of shot; (2) species-specific factors and diet influencing absorption and dissolution; and (3) environmental conditions, especially cold, which can influence the toxicity of lead in birds. Significant reproductive impairment has been demonstrated following exposure to a single lead shot pellet. Estimates of biologically significant exposure to lead in upland bird populations are currently unreliable, however.

Although a dose-response profile of lead shot toxicosis in upland species has been only minimally delineated, sufficient information is available to provide a reasonable estimate of a threshold exposure level that results in mortality of doves and galliform species.

\section{Ecological significance}

The ecological significance of mortalities associated with lead shot must be viewed within the context of cumulative risks to avian populations. These risks include decreased availability of high-quality habitat, habitat fragmentation, hunting pressure, and the persistent highly toxic nature of lead shot. The relative magnitudes of these factors must be assessed. The exposure scenario evident from available data is one in which there is a coincident occurrence of significant concentrations of bird populations and lead shot in habitat managed explicitly to attract birds. The deposition of spent lead shot associated with upland game hunting is almost five times greater (14,000 tons vs. 3,000 tons/annum) [8] than that associated with waterfowl hunting.

In addition to the ecological significance associated with the possible mortality of avian populations (mourning doves) exposed to lead shot, shot may be transferred in the food chain to predators through the ingestion of shot remaining in tissues of consumed prey. This combination of concerns formed the impetus for actions to ban lead shot for waterfowl hunting and is likewise a concern for predators exposed to lead shot available through the terrestrial food chain.

\section{RISK MANAGEMENT}

This ecological risk assessment has been developed to facilitate future evaluation of actions necessary to mitigate, reduce, or eliminate possible risks to upland bird populations from spent lead shot. Regulatory actions are possible under the MBTA or the ESA.

The EPA is currently reviewing public comment to a proposed ban of lead sinkers under Section 6 of TSCA. Although the toxicoses of lead sinkers and lead shot are similar, both the type of exposure and quantity of lead available in the environment vary between the two uses. In addition, potential regulation of spent lead shot deposited in high densities at shooting ranges and preserves as a hazardous waste under the Resource Conservation and Recovery Act (RCRA) or as a discharged pollutant under Section 301 of the Clean Water Act is possible. A number of legal interpretations and at least one federal court ruling indicate that remedial actions are necessary; remediation is taking place in several states. It appears probable that failure to address the risks from lead shot associated with upland hunting and target shooting could result in later regulatory action, placing significant cost burdens on landowners, states, and the federal government.

\section{Management approaches}

A finding of unreasonable risk to the environment under the TSCA is intended to be a judgement under which the decisionmaker determines that risks to the environment from the chemical in question outweigh the burden to society of potential regulations. Section 6 does not require a factual certainty, and the law recognizes that the EPA must, of necessity, base its action on scientific theories, consideration of projections from available data, and utilization of models and reasonable assumptions. Any decision regarding the regulation of lead shot will be facilitated by the fact that substitute nontoxic materials are already developed, or are being developed, that perform as well or nearly as well for the intended use [8]. Increased cost does not appear to be considered a significant factor by hunters [96].

Some difficulties in the enforcement of zone-designated areas where the use of lead shot is banned include the mobility of game birds and the volume of shot currently being deposited. Although a ban on lead shot production is one regulatory option, the panel encourages the EPA and other potential regulators to involve potentially affected parties (i.e., stakeholders) in devising solutions (both regulatory and nonregulatory) to reduce or eliminate the risks associated with lead shot in upland ecosystems.

Benefits to the hunting public, as well as to the sport hunting industry, would accrue from the elimination of lead shot from the environment. An enlightened sport hunting industry desires a sustainable recreational activity. Demographic data suggest that there are increasing numbers of people participating in upland game bird hunting, skeet shooting, and sport clay hunting [97]. Associated with this increased activity are declines in highquality habitats and a concentration of lead shot in remaining habitats.

In the current business environment, product stewardship is an important consideration, and this perspective may provide insights and options for solutions to addressing risks from lead shot. Due to the inherent toxicity of lead, its use in an application that would concentrate it in specific geographic areas (e.g., prime wildlife habitat, game preserves, and sport hunting ranges) would be discouraged unless there were specific plans for remediation. This issue can be viewed as a waste-product disposal issue. Once again, it would be desirable to bring all stakeholders (hunters, environmentalists, firearm and munitions manufacturers, state and federal wildlife agencies) together to design 
solutions compatible with sustained, healthy avian populations. Subsequent discussions regarding conclusions associated with economic factors, using concepts of product life-cycle analysis, should provide mitigation options, remedial actions, and responsible decisions based on sound scientific, economic, and social considerations. Indeed, these actions might occur without specific government regulatory action.

A formal process for involving stakeholders during regulatory option development, although not explicitly incorporated into the current risk assessment and risk management process, may prove important in designing solutions to the lead shot problem. Greater stakeholder involvement is consistent with the EPA's recent adoption of ecosystem management principles and place-based regulatory paradigm. At a minimum, the key stakeholder groups would include the NSSF, National Rifle Association, International Association of Fish and Wildlife Agencies, the NWF, Quail Unlimited, Environmental Defense Fund, EPA Office of Solid Waste and Office of Water, arms and ammunition manufacturers, the USFWS, and state departments of natural resources.

\section{Regulatory impact analysis}

A number of existing laws have clearly identified mandates to protect and maintain viable, healthy, and sustained populations of native species. Migratory and game birds are protected under these provisions, yet are under increasing threat from a variety of anthropogenic stressors. The panel recommends consideration of cost-benefit issues to identify economic efficiencies while we seek to reduce the ecological risks associated with lead shot in the environment. The panel cautions against the use of prevalence (e.g., mortality) data in conducting cost-benefit analyses on the regulation of lead shot in upland hunting and shooting ranges. For the reasons stated earlier, use of prevalence data is fraught with uncertainties. Use of monetized values, derived from prevalence data, will be equally problematic. In addition, a full accounting of the economic consequences to affected parties must factor in the potential long-term, persistent losses to game bird populations from lead shot exposure as well as the costs of potential hazardous waste remediation at shooting ranges and preserves where required by state or federal law.

\section{Conclusions}

Data suggest substantial risks of widespread and repeated mortality in mourning doves exposed to high densities of spent lead shot in habitats where hunting or shooting is concentrated. Hunting and shooting ranges are distributed throughout the United States and Canada, and their use and numbers are increasing. Documented cases of lead poisoning in other upland birds and raptors are also of concern, but the extent of risk to these and other species cannot be ascertained from the available data. The panel recommends that additional research be conducted to determine (1) the proportion of the mourning dove population that is at high risk; (2) the identity of other upland bird species (especially raptors) that are at risk; and (3) whether this risk is large enough to reduce population levels significantly and therefore merit regulatory action. We also recommend a more open process, fully involving all stakeholders, than is currently envisioned in the EPA's risk management process.

Acknowledgement-The authors thank the National Wildlife Federation, National Shooting Sports Foundation, and the United States Environment Protection Agency for their financial support of the "Lead Shot Exposure in Non-waterfowl Species: An Ecological Risk Assessment" workshop. We thank Beth Ann Cushman for her efforts in coordinating the workshop and for her time helping the authors develop and edit this manuscript.

\section{REFERENCES}

1. U.S. Environmental Protection Agency. 1992. Framework for ecological risk assessment. EPA/630/R-92/001. Washington, DC.

2. Bates, F.Y., D.M. Barnes and J.M. Higbee. 1968. Lead toxicosis in mallard ducks. Bull. Wildl. Dis. Assoc. 4:116-125.

3. Irwin, J.C. and L.H. Karstad. 1972. The toxicity for ducks of disintegrated lead shot in a simulated-marsh environment. J. Wildl. Dis. 8:149-154.

4. Longcore, J.R., R. Andrews, L.N. Locke, G.E. Bagley and L.T. Young. 1974. Toxicity of lead and proposed substitute to mallards. U.S. Fish Wildl. Serv. Spec. Sci. Rep. 183.

5. Bellrose, F.C. 1959. Lead poisoning as a mortality factor in waterfowl populations. Ill. Nat. Hist. Surv. Bull. 27:235-288.

6. Lumeij, J.T. 1985. Clinicopathologic aspects of lead poisoning in birds: A review. Vet. Q. 7:133-138.

7. Sanderson, G.C. and F.C. Bellrose. 1986. A review of the problem of lead poisoning in waterfowl. Ill. Nat. Hist. Surv. Spec. Publ. 4.

8. U.S. Fish and Wildlife Service. 1986. The use of lead for hunting migratory birds in the United States. Final Supplemental Environmental Impact Statement on the Use of Lead Shot for Hunting Migratory Birds. FES 86-16. Office of Migratory Bird Management, Washington, DC.

9. Sadler, K.C. 1993. Mourning dove harvest. In T.S. Baskett, M.W. Sayer, R.E. Tomlinson and R.E. Mirarchi, eds., Ecology and Management of the Mourning Doves. Stackpole Books, Harrisburgh, PA, USA, pp. 449-458.

10. Lewis, J.C. and E. Legler, Jr. 1968. Lead shot ingestion by mourning doves and incidence in soil. J. Wildl. Manage. 32:476482.

11. Best, T.L., T.E. Garrison and C.G. Schmitt. 1992. Availability and ingestion of lead shot by mourning doves (Zenaida macroura) in southeastern New Mexico. Southwest Nat. 37:287-292.

12. Locke, L.N. and M. Friend. 1992. Lead poisoning of avian species other than waterfowl. In D.J. Pain, ed., Lead Poisoning in Waterfowl. Special Publication 16. Waterfowl Wetlands Research Bureau, Slimbridge, Gloucester, UK, pp. 19-22.

13. Stansley, W., L. Widjeskog and D.E. Roscoe. 1992. Lead contamination and mobility in surface water at trap and skeet ranges. Bull. Environ. Contam. Toxicol. 49:640-647.

14. Eisler, R. 1988. Lead hazards to fish, wildlife and invertebrates: A synoptic review. U.S. Fish Wildl. Serv. Biol. Rep. 85:1-133.

15. Bellrose, F.C. 1951. Effects of ingested lead shot upon waterfowl populations. Trans. N. Am. Wildl. Nat. Resour. Conf. 16:125-133.

16. Pattee, O.H., S.N. Wiemeyer, B.M. Mulhern, L. Sileo and J.W. Carpenter. 1981. Experimental lead shot poisoning in bald eagles. J. Wildl. Manage. 45:806-810.

17. Kendall, R.J., R.T. DiGuilio and P.F. Scanlon. 1982. The toxicology of ingested lead shot in ringed turtle doves. Arch. Environ. Contam. Toxicol. 11:259-263.

18. Buerger, T.T., R.E. Mirarchi and M.E. Lisano. 1986. Effects of lead shot ingestion on captive mourning dove survivability and reproduction. J. Wildl. Manage. 50:1-8.

19. Castrale, J.S. and M. Oster. 1993. Lead and $\delta$-aminoleuvalinic acid dehydrogenase in the blood of mourning doves dosed with lead shot. Proc. Indian Natl. Sci. Acad. 102:265-272.

20. Weyhrauch, B.B. 1986. Waterfowl and lead shot. Environmental Law 16:883-934.

21. Zakrzewski, S.F. 1991. Principles of Environmental Toxicology. American Chemical Society, Washington, DC, USA.

22. Blus, L.J., C.J. Henny, D.J. Hoffman and R.A. Grove. 1991. Lead toxicosis in tundra swans near a mining and smelting complex in northern Idaho. Arch. Environ. Contam. Toxicol. 21:549555.

23. Avian Effects Dialogue Group. 1989. Pesticides and Birds: Improving Impact Assessment. The Conservation Foundation, Washington, DC, USA.

24. Sabine, N. and W.D. Klimstra. 1985. Ecology of bald eagles wintering in southern Illinois. Trans. Ill. State Acad. Sci. 78:1324.

25. Pattee, O.H. and S.K. Hennes. 1983. Bald eagles and waterfowl: The lead shot connection. Proceedings, 48th North American 
Wildlife Conference 1983, Washington, DC, USA, March 19-24, pp. 230-237.

26. U.S. Department of the Interior, Fish and Wildlife Service and U.S. Department of Commerce, Bureau of the Census. 1993. 1991 National Survey of Fishing, Hunting, and Wildlife-Associated Recreation. U.S. Government Printing Office, Washington, DC.

27. Anderson, W.L. and S.P. Havera. 1989. Lead poisoning in Illinois waterfowl (1977-1988) and implementation of nontoxic shot regulations. Ill. Nat. Hist. Surv. Biol. Notes 133.

28. Castrale, J.S. 1989. Availability of spent lead shot in fields managed for mourning dove hunting. Wildl. Soc. Bull. 17:184-189.

29. Fredrickson, L.H., T.S. Baskett, G.K. Brakhage and V.C. Cravens. 1977. Evaluating cultivation near duck blinds to reduce lead poisoning hazard. J. Wildl. Manage. 41:624-631.

30. Peters, M.S. and A.D. Afton. 1993. Effects of deep tillage on redistribution of lead shot and chufa flatsedge at Catahoula Lake, Louisiana. Wildl. Soc. Bull. 21:471-479.

31. Anderson, W.L. 1975. Lead poisoning in waterfowl at Rice Lake, Illinois. J. Wildl. Manage. 39:264-270.

32. Pain, D.J. 1991. Lead shot densities and settlement rates in Camargue Marshes, France. Biol. Conserv. 57:273-286.

33. Jorgensen, S.S. and M. Willems. 1987. The fate of lead in soils: The transformation of lead pellets in shooting-range soils. Ambio 16:11-15.

34. Haas, G.H. 1977. Unretrieved shooting loss of mourning doves in north-central South Carolina. Wildl. Soc. Bull. 5:123-125.

35. Roscoe, D.E., L. Widjeskog and W. Stansley. 1989. Lead poisoning of northern pintail ducks feeding in a tidal meadow contaminated with shot from a trap and skeet range. Bull. Environ. Contam. Toxicol. 42:226-233.

36. Whitehead, P.J. and K. Tschirner. 1991. Lead shot ingestion and lead poisoning of magpie geese Anseranas semipalmata foraging in a northern Australian hunting reserve. Biol. Conserv. 58: 99-118.

37. Trost, R.E. 1981. Dynamics of grit selection and retention in captive mallards. J. Wildl. Manage. 45:64-73.

38. Hall, S.L. and F.M. Fisher, Jr. 1985. Lead concentration in tissues of marsh birds: Relationship of feeding habits and grit preference to spent shot ingestion. Bull. Environ. Contam. Toxicol. 35:1-8.

39. Pain, D.J. 1990. Lead shot ingestion by waterbirds in the Camargue, France: An investigation of levels and interspecific differences. Environ. Pollut. 66:273-285.

40. McClure, H.E. 1950. Discussions. Trans. N. Am. Wildl. Conf. 15:169.

41. Franson, J.C. and S.G. Hereford. 1994. Lead poisoning in a Mississippi sandhill crane. Wilson Bull. 106:766-768.

42. Roscoe, D.E., W. Stansley and L. Widjeskog. 1990. Lead poisoning of waterfowl and mobility of lead from trap and skeet ranges in New Jersey. Proceedings, 6th International Conference on Wildlife Diseases, Berlin, Germany, August 6-11, p. 53.

43. Platt, J.B. 1976. Bald eagles wintering in a Utah desert. Am. Birds 30:783-788.

44. Pain, D.J. and C. Amiard-Triquet. 1993. Lead poisoning of raptors in France and elsewhere. Ecotoxicol. Environ. Saf. 25: 183-192.

45. Pain, D.J., C. Amiard-Triquet, C. Bavoux, G. Burneleau, L. Eon and P. Niclau-Guillaumet. 1993. Lead poisoning in wild marsh harriers (Circus aeruginosus) in the Camargue and Charente-Maritime, France. Ibis 135:379-386.

46. Locke, L.N. and G.E. Bagley. 1967. Lead poisoning in a sample of Maryland mourning doves. J. Wildl. Manage. 31:515-518.

47. Bagley, G.E. and L.N. Locke. 1967. The occurrence of lead in tissues of wild birds. Bull. Environ. Contam. Toxicol. 2:297-305.

48. Anderson, W.L. and S.P. Havera. 1985. Blood lead, protoporphyrin, and ingested lead shot for detecting lead poisoning in waterfowl. Wildl. Soc. Bull. 13:26-31.

49. Clausen, B. and C. Wolstrup. 1979. Lead poisoning in game from Denmark. Dan. Rev. Game Biol. 11:1-22.

50. Borg, K. 1975. Viltsjukdomar. L.T.'s Forlag, Helingborg, Sweden.

51. Heitmeyer, M.E., L.H. Fredrickson and D.D. Humburg. 1993. Further evidence of biases associated with hunter-killed mallards. J. Wildl. Manage. 57:733-740.

52. Lumeij, J.T. and H. Scholten. 1989. A comparison of two methods to establish the prevalence of lead shot ingestion in mallards
Anas platyrhynchos from The Netherlands. J. Wildl. Dis. 25:297299.

53. Montalban, F. III and T.C. Hines. 1986. An improved x-ray technique for investigating ingestion of lead by waterfowl. In J.S. Feierabend and A.B. Russell, eds., Lead Poisoning in WaterfowlA Workshop. National Wildlife Federation, Washington, DC, USA, pp. 5-10.

54. Furness, J.C. and R.J. Robel. 1989. X-ray and visual detection of shot in waterfowl gizzards and marsh substrate. Trans. Kans. Acad. Sci. 92:79-82.

55. Klaassen, C.D., M.O. Amdur and J. Doull, eds. 1986. Casarett and Doull's Toxicology, 3rd ed. Macmillan, New York, NY, USA.

56. Jubb, K.V.F. and C.R. Huxtable. 1993. The nervous system. In K.V.F. Jubb, P.C. Kennedy and N. Palmer, eds., Pathology of Domestic Animals, 4th ed. Academic, San Diego, CA, USA, pp. 348351.

57. Beyer, W.N., J.W. Spann, L. Sileo and J.C. Franson. 1988. Lead poisoning in six captive avian species. Arch. Environ. Contam. Toxicol. 17:121-130.

58. McConnell, C.A. 1968. Experimental lead poisoning of bobwhite quail and mourning doves. Proc. Annu. Conf. Southeast Assoc. Game Fish Comm. 21:208-219.

59. Kendall, R.J. and P.F. Scalon. 1984. The toxicology of lead shot ingestion in ringed turtle doves under conditions of cold exposure. J. Environ. Pathol. Toxicol. Oncol. 5:183-192.

60. Selye, H. 1973. The evolution of the stress concept. Am. Sci. 61: 692-699.

61. Marn, C.M., R.E. Mirarchi and M.E. Lisano. 1988. Effects of diet and cold exposure on captive female mourning doves dosed with lead shot. Arch. Environ. Contam. Toxicol. 17:589-594.

62. Kendall, R.J., H.P. Veit and P.F. Scanlon. 1981. Histological effects and lead concentrations in tissues of adult male ringed turtle doves that ingested lead shot. J. Toxicol. Environ. Health 8:649-658.

63. Veit, H.P., R.J. Kendall and P.F. Scanlon. 1983. The effect of lead shot ingestion on the testes of adult ringed turtle doves (Streptopelia risoria). Avian Dis. 27:442-452.

64. Damron, B.L. and H.R. Wilson. 1975. Lead toxicity of bobwhite quail. Bull. Environ. Contam. Toxicol. 14:489-496.

65. Fimreite, N. 1984. Effects of lead shot ingestion in willow grouse. Bull. Environ. Contam. Toxicol. 33:121-126.

66. Gjerstad, K.O. and I. Hanssen. 1984. Experimental lead poisoning in willow ptarmigan (Lagopus lagopus). J. Wildl. Manage. 48: $1018-1022$.

67. Reiser, M.H. and S.A. Temple. 1981. Effects of chronic lead ingestion in birds of prey. In J.E. Cooper and A.G. Greenwood, eds., Recent Advances in the Study of Raptor Diseases. Chiron Press, Keighley, UK, pp. 21-25.

68. Stendell, R.C. 1980. Dietary exposure of kestrels to lead. J. Wildl. Dis. 44:527-530.

69. Franson, J.C., L. Sileo, O.H. Pattee and J.F. Moore. 1983. Effects of chronic dietary lead in American kestrels (Falco sparverius). J. Wildl. Dis. 19:110-113.

70. Pattee, O.H. 1984. Eggshell thickness and reproduction in American kestrels exposed to chronic dietary lead. Arch. Environ. Contam. Toxicol. 13:29-34.

71. Custer, T.W., J.C. Franson and O.H. Pattee. 1984. Tissue lead distribution and hematologic effects in American kestrels (Falco sparverius) fed biologically incorporated lead. J. Wildl. Dis. 20: 39-43.

72. Hoffman, D.J., J.C. Franson, O.H. Pattee, C.M. Bunck and A. Anderson. 1985. Survival, growth, and accumulation of ingested lead in nestling American kestrels. Arch. Environ. Contam. Toxicol. 14:89-95.

73. Carrington, M.E. and R.E. Mirarchi. 1989. Effects of lead shot ingestion on free-ranging mourning doves. Bull. Environ. Contam. Toxicol. 43:173-179.

74. Morgan, G.W., F.W. Edens, P. Thaxton and C.R. Parkhurst. 1975. Toxicity of dietary lead in Japanese quail. Poult. Sci. 54: 1636-1642.

75. Edens, F.W., E. Benton, S.J. Bursian and G.W. Morgan. 1976. Effect of dietary lead on reproduction performance in Japanese quail, (Coturnix coturnix japonica). Toxicol. Appl. Pharmacol. 38:307-314.

76. Mazliah, J., S. Barron, E. Bental and I. Reznik. 1989. The effect 
of chronic lead intoxication in mature chickens. Avian Dis. 33: $566-570$.

77. Hoffman, D.J., O.H. Pattee, S.N. Wiemeyer and B.M. Mulhern. 1981. Effects of lead shot ingestion on d-aminolevulinic acid dehydratase activity, hemoglobin concentration, and serum chemistry in bald eagles. J. Wildl. Dis. 17:423-431.

78. Hoffman, D.J., J.C. Franson, O.H. Pattee, C.M. Bunck and H.C. Murray. 1985. Biochemical and hematological effects of lead ingestion in nestling American kestrels. Comp. Biochem. Physiol. C 80:431-439.

79. Kendall, R.J. and P.F. Scanlon. 1981. Effects of chronic lead ingestion on reproductive characteristics of ringed turtle doves (Streptopelia risoria) and on tissue lead concentrations of adults and their progeny. Environ. Pollut. Ser. A. 26:203-213.

80. Jordan, J.S. and F.C. Bellrose. 1950. Shot alloys and lead poisoning in waterfowl. Trans. N. Am. Wildl. Conf. 15:155-170.

81. Carlson, B.L. and S.W. Nielson. 1985. Influence of dietary calcium on lead poisoning in mallards fed natural foods. Bull. Environ. Contam. Toxicol. 32:417-428.

82. Dolton, D.D. 1994. Mourning dove breeding population status. Report 301.846/0001. U.S. Fish and Wildlife Service, Washington, DC.

83. Wobeser, G. and A.G. Wobeser. 1992. Carcass disappearance and estimation of mortality in a simulated die-off of birds. J. Wildl. Dis. 28:548-554.

84. Philibert, H., G. Wobeser and R.G. Clark. 1993. Counting dead birds: Examination of methods. J. Wildl. Dis. 29:284-289.

85. Temple, S.A. and J.A. Wiens. 1989. Bird populations and environmental changes: Can birds be bio-indicators? Am. Birds $\mathbf{4 3}$ : 260-270.

86. Shrader-Frechette, K.S. 1994. Science, environmental risk assessment, and the frame problem. BioScience 44:548-551.

87. Schmitt, S.A. 1969. Measuring Uncertainty: An Elementary Introduction to Bayesian Statistics. Addison-Wesley, Reading, MA, USA.

88. Dunks, J.H., R.E. Tomlinson, H.M. Reeves, D.D. Dolton, C.E. Braun and T.P. Zapatka. 1982. Migration, harvest and population dynamics of mourning doves banded in the Central Management Unit, 1967-1977. U.S. Fish Wildl. Serv. Spec. Sci. Rep. 249:1-128.

89. Tomlinson, R.E., D.D. Dolton, H.M. Reeves, J.D. Nichols and L.A. McKibben. 1988. Migration, harvest, and population characteristics of mourning doves banded in the Western Management Unit, 1964-1977. U.S. Fish Wildl. Serv. Spec. Sci. Rep. 13:1101.

90. Geissler, P.H. et al. 1987. Mourning dove nesting: Seasonal patterns and effects of September hunting. U.S. Fish Wildl. Serv. Resour. Publ. 168

91. DeAngelis, D.L. 1994. What food web analysis can contribute to wildlife toxicology. In R.J. Kendall and T.E. Lacher, Jr., eds.,
Wildlife Toxicology and Population Modeling: Integrated Studies of Agroecosystems. Lewis, Boca Raton, FL, USA, pp. 365-382.

92. Lacher, T.E., Jr. Direct and indirect pathways in spatially structured habitats. In R.J. Kendall and T.E. Lacher, Jr., eds., Wildlife Toxicology and Population Modeling: Integrated Studies of Agroecosystems. Lewis, Boca Raton, FL, USA, pp. 139-143.

93. Galindo, J.C., R.J. Kendall, C.J. Driver and T.E. Lacher. 1985. The effect of methyl parathion on susceptibility of bobwhite quail (Colinus virginianus) to domestic cat predation. Behav. Neural. Biol. 43:21-36.

94. Kendall, R.J. and T.E. Lacher, Jr., eds. 1994. Wildlife Toxicology and Population Modeling: Integrated Studies of Agroecosystems. Lewis, Chelsea, MI, USA.

95. Williams, B.K. and J.D. Nichols. 1990. Modeling and the management of migratory birds. Natural Resource Modeling 4:273311.

96. Lakhani, H. 1982. Benefit-cost analysis: Substituting iron for lead shot in waterfowl hunting in Maryland. J. Environ. Manage. 14:201-208.

97. JFB, Inc. 1992. Black's Wing \& Clay: The Sportsman's Annual Guide to Wing \& Clay Shooting Locations, Vol. 1. Red Bank, NJ, USA.

98. Manninen, S. and N. Tanskanen. 1993. Transfer of lead from shotgun pellets to humus and three plant species in a Finnish shooting range. Arch. Environ. Contam. Toxicol. 24:410-414.

99. Ma, W. 1989. Effect of soil pollution with metallic lead pellets on lead bioaccumulation and organ/body weight alterations in small mammals. Arch. Environ. Contam. Toxicol. 18:617-622.

100. Buerger, T.T., R.E. Mirarchi and M.E. Lisano. 1983. Lead shot ingestion in a sample of Alabama mourning doves. J. Ala. Acad. Sci. 54:119.

101. Kendall, R.J. and P.F. Scanlon. 1979. Lead concentrations in mourning doves collected from middle Atlantic game management areas. Proc. Annu. Conf. Southeast Assoc. Fish Wildl. Agencies 33:165-172.

102. Kendall, R.J. and P.F. Scanlon. 1982. Tissue lead concentrations and blood characteristics of mourning doves from southwestern Virginia. Arch. Environ. Contam. Toxicol. 11:269-272.

103. Kendall, R.J., G.W. Norman and P.F. Scanlon. 1984. Lead concentration in ruffed grouse collected from southwestern Virginia. Northwest Sci. 58:14-17.

104. Dement, S.H., J.J. Chisolm, Jr., M.A. Eckhaus and J.D. Strandberg. 1987. Toxic lead exposure in the urban rock dove. J. Wildl. Dis. 23:273-278.

105. Westemeier, R.I. 1966. Apparent lead poisoning in a wild bobwhite. Wilson Bull. 78:471-472.

106. Campbell, H. 1950. Quail picking up lead shot. J. Wildl. Manage. 14:243-244.

107. Hunter, B.F. and M.N. Rosen. 1965. Occurrence of lead poisoning in a wild pheasant (Phasianus colchicus). Calif. Fish Game 51:207.

108. Stone, W.B. and S.A. Butkas. 1972. Lead poisoning in a wild turkey. N. Y. Fish Game J. 25:169. 